\title{
$1-1-1979$
}

\section{Habeas Corpus and Freedom of Speech}

Michael L. Wells

University of Georgia School of Law, mwells@uga.edu

D bepress

\section{Repository Citation}

Michael L. Wells, Habeas Corpus and Freedom of Speech (1979),

Available at: https://digitalcommons.law.uga.edu/fac_artchop/374

This Article is brought to you for free and open access by the Faculty Scholarship at Digital Commons @ University of Georgia School of Law. It has been accepted for inclusion in Scholarly Works by an authorized administrator of Digital Commons @ University of Georgia School of Law. Please share how you have benefited from this access For more information, please contact tstriepe@uga.edu. 


\title{
HABEAS CORPUS AND FREEDOM OF SPEECH
}

\author{
Michael Wells*
}

Discussion concerning the proper scope of federal habeas corpus for state prisoners usually focuses upon the use of the writ as a federal remedy for procedural errors of constitutional magnitude in state criminal trials. Proponents of "liberal" habeas argue that only federal courts can adequately protect the federal procedural rights of state criminal defendants, ${ }^{1}$ while critics contend that the states' interest in administering their criminal laws free froin federal interference overshadows the asserted benefits. ${ }^{2}$ Setting the proper scope of the writ requires a weighing of these competing values.

The focus on procedure is appropriate, because the vast majority of habeas petitions are brought by prisoners convicted of ordinary crimes contending that procedural rules ${ }^{3}$ were violated in the process that resulted in their confinements. Solnetimes, however, the crime it-

* Assistant Professor, University of Georgia School of Law; B.A. 1972, J.D. 1975, University of Virginia. The author wishes to thank John D. Eure, William D. Iverson and Graham B. Strong for their helpful comments on a draft of this Article.

THE FOLLOWING CITATIONS WILL BE USED IN THIS ARTICLE:

P. Bator, P. Mishkin, D. Shapiro \& H. Wechsler, Hart and Wechsler's The Federal Courts AND THE FEDERAL System (2d ed. 1973) [hereinafter cited as HART \& WechSLER];

Amsterdam, Criminal Prosecutions Affecting Federally Guaranteed Civil Rights: Federal Removal and Habeas Corpus Jurisdiction to Abort State Court Trial, 113 U. PA. L. REv. 793 (1965) [heremafter cited as Amsterdam];

Bator, Finality in Criminal Law and Federal Habeas Corpus for State Prisoners, 76 HARv. L. REV, 441 (1963) [heremafter cited as Bator];

Cover \& Aleinikoff, Dialectical Federalism: Habeas Corpus and the Court, 86 YALE L.J. 1035 (1977) [hereinafter cited as Cover \& Aleinikoff];

Friendly, Is Innocence Irrelevant? Collateral Attack on Criminal Judgments, 38 U. CHI. L. REv. 142 (1970) [hereinafter cited as Friendly];

Shapiro, Federal Habeas Corpus: A Study in Massachusetts, 87 HARv. L. REv. 321 (1973) [hereinafter cited as Shapiro];

Developments in the Law-Federal Habeas Corpus, 83 HaRv. L. Rev. 1038 (1970) [hereinafter cited as Developments];

Note, The First Amendment Overbreadth Doctrine, 83 HARv. L. REv. 844 (1970) [heremafter cited as First Amendment-Overbreadth].

1. See Cover \& Aleinikoff 1037-44; Wright \& Sofaer, Federal Habeas Corpus for State Prisoners: The Allocation of Fact-Finding Responsibility, 75 YALE L.J. 895, 897-99 (1966).

2. See Schneckloth v. Bustamonte, 412 U.S. 218, 259-66 (1973) (Powell, J., concurring); Bator 444-53, 503-07.

3. The procedural rules at issue in these cases are rules mandated by the fourth, fifth and sixth amendments, made applicable to state trials by the due process clause of the fourteenth amendment, and procedural due process rules grounded in the fourteenth amendment. In this 
self is open to constitutional attack. A statute barring the distribution of contraceptives to single, but not to married, persons may be attacked on an equal protection theory. ${ }^{4}$ Or a statute punishing a person who maintams a building which is "resorted to by narcotic drug addicts for the purpose of using narcotic drugs and/or which is used for the illegal keeping or selling of the same" may be challenged on the ground that it is too vague to give an individual fair warning of what is proscribed. ${ }^{5}$

This Article will examine another class of substantive attacks on habeas-those asserting that the petitioner's confinement violates his first amendment rights of free speech, press or assembly. The thesis is that when these rights are at issue, the considerations supporting broad habeas are stronger, and the costs of habeas are lower, than when the petitioner is asserting the violation of a federal procedural right. As a result, the necessary choice of values is more easily resolved in favor of broad first amendment habeas than it is for broad procedural habeas. ${ }^{6}$

Essential to this analysis is the premise that a habeas court may legitmately distinguish among constitutional rights. This premise rests on the functional differences between habeas proceedings and appellate review, where such distinctions among rights are not permissible. The reasoning underlying the premise is developed im Part I. Part II describes the justifications for according distinctive and liberal treatment to free speech claims. Part III considers some of the possible consequences of drawing the suggested distinction between first amendment and procedural habeas. It is suggested that different rules might govern the cognizability of issues in habeas, as well as governing other aspects of habeas relief, such as custody, exhaustion of state remedies, prospective or retroactive application of new decisions, and procedural default. The proper approacli to overbreadth review in habeas is also considered. ${ }^{7}$

Article the term "procedural habeas" is used as a shorthand method of referring to these attacks upon state convictions.

4. Eisenstadt v. Baird, 405 U.S. 438 (1972) (writ granted).

5. English v. Virginia Probation \& Parole Bd., 481 F.2d 188, 189 (4th Cir. 1973) (writ denied).

6. No position is advanced here as to the proper limits upon habeas for procedural claims, nor is it argued that first amendment issues must be accorded better treatment as a matter of constitutional law. Rather, the effort is to show that a principled distinction can be drawn between free speech and procedural rights by the Congress or the Supreme Court in determining the appropriate scope of habeas.

7. Throughout this Article the interest im greater protection of constitutional rights through habeas is weighed against the state's interest in values of finality and federalisin. It might be objected that rights, first amendment or otherwise, are not interests to be weighed agamst other values but must be observed in spite of costs to the state's interests. See Stone v. Powell, 428 U.S. 465, 522 (1976) (Brennan, J., dissenting) (complaining that Slone, by limiting habeas for fourth amendment claims, "marks the triumph of those who have sought to establish a hierarchy of 


\section{The Function of The Writ}

The Supreme Court greatly expanded the availability of habeas corpus in the 1950s and 1960s. Brown v. Allen ${ }^{8}$ held that any constitutional question could be raised on habeas. Fay v. Noia ${ }^{9}$ allowed a prisoner who had not properly preserved his constitutional claim in the state courts nevertheless to assert the issue in a petition for habeas corpus, so long as he had not "deliberately bypassed" state processes. Jones v. Cunningham ${ }^{10}$ held that physical confinement was not necessary in order to ineet the requirement that the petitioner be "in custody." After Brown, Fay and Jones, habeas corpus was available to attack virtually any constitutional defect in a state criminal trial. It became quite easy to regard the writ as a kind of appellate review of state criminal judgments, providing a federal forum to guarantee enforcement of the many new federal procedural rights that were made applicable to the states in those decades. ${ }^{11}$

No doubt this account accurately reflects the Warren Court's con-

constitutional rights, and to deny for all practical purposes a federal forum for review of those rights that this Court deems less worthy or important"); $f f$ Cover \& Aleinikoff 1092 (suggesting that a cost-benefit analysis and a focus on the functions served by rights, as means of determining whether claims will be heard in habeas, are "inconsistent with the very idea of rights").

This approach fails to appreciate the nature of the balancing that is at issue. The question in setting the scope of habeas is not whether someone holds a right against the state or whether some state interest might outweigh a person's rights. The question is what rules will be devised for the protection of rights. See H.L.A. HART, THE CONCEPT OF LAW 77-96 (1961) (distinguishing between primary rules, "which are concerned with the actions that individuals must or must not do," and secondary rules, which "specify the ways in which the primary rules may be conclusively ascertained, introduced, eliminated, varied, and the fact of their violation conclusively determined," id. 92). The existence of a right implies a means for enforcing it, but the conclusion does not follow that other interests may not be taken into account in devising those remedial procedures. For example, a newspaper may assert its first amendment rights in defense of a hibel suit. But, if the paper loses, the rules of collateral estoppel bar it from relitigating the issue, however wrong the result may have been. The cost to other values would be too great. When a criminal defendant unsuccessfully asserts his rights at trial and on appeal and is imprisoned, his interest in freedom froin unconstitutional confinement may, but does not always, outweigh the competing values and permit relief in habeas. To recognize that other values may diminisl the avenues available for protection of constitutional rights is not to insist that rights themselves must be balanced against the state's interests. It is, rather, to appreciate the imperfection of legal procedures as a means of protecting rights and the need to husband the limited econormic, political and moral resources available to the legal system. See Bator 451 .

8. 344 U.S. 443 (1953).

9. 372 U.S. 391 (1963).

10. 371 U.S. 236 (1963).

11. See Stone v. Powell, 428 U.S. 465, 511-12 (1976) (Brennan, J., dissenting); Mackey v. United States, 401 U.S. 667, 685-87 (1971) (Harlan, J., concurring and dissenting); Geagin v. Gavin, 181 F. Supp. 466, 469 (D. Mass. 1960), affd, 292 F.2d 244 (lst Cir. 1961), cert. denied, 370 U.S. 903 (1962). See also Cover \& Aleinikoff 1037-44; Wright \& Sofaer, supra note 1, at 897-99. 
ception of the proper role for habeas corpus. ${ }^{12}$ Clearly, however, this conception is at odds with the historic understanding of the writ as an extraordinary remedy for extraordinary restraints on liberty. ${ }^{13}$ In its early days, a petition for habeas corpus was permitted only to challenge executive detentions or the jurisdiction of the committing court. ${ }^{14}$ Later the concept of jurisdiction was expanded to allow attacks on the constitutionality of the statutes underlying convictions, illegal sentences and a few other inatters. ${ }^{15}$ Later still a prisoner was permitted to raise constitutional claims that had not been fully and fairly considered in the state courts, ${ }^{16}$ or that rested on inatters outside the state court record, and thus could not be considered on appeal. ${ }^{17}$ That was where the law stood at the time of Brown. ${ }^{18}$

For most of its history, then, habeas corpus was not a quasi-appellate review of state criminal convictions but rather served the more elusive function of remedying restraints on liberty thought to be "extraordinary," 19 "intolerable," 20 contrary to "basic justice,"21 or which carried "a connotation of outrage" 22 or were "affronts to the conscience of a civilized society." 23 As the steady expansion of the availability of habeas reveals, the Court's judgments about the kinds of claims ineeting this slippery test changed over the years. By the time Fay was decided, the Court could assert that the intolerable restraints that habeas was intended to reinedy included any constitutional claim. ${ }^{24}$ Not everyone agreed with that conclusion, ${ }^{25}$ but the significant

12. See Stone v. Powell, 428 U.S. 465,512 (1976) (Brennan, J., dissenting) ("district courts sitting in habeas [have been cast] in the role of surrogate Supreine Courts").

13. See Schncckloth v. Bustamonte, 412 U.S. 218, 252-59 (1973) (Powcll, J., concurring); Fay v. Noia, 372 U.S. 391, 448-76 (1963) (Harlan, J., dissenting); Brown v. Allen, 344 U.S. 443, 532-48 (1953) (Jackson, J., concurring in result).

14. See Ex parte Watkins, 28 U.S. (3 Pet.) 193 (1830); Bator 466.

15. See Ex parte Siebold, 100 U.S. 371 (1879); Ex parte Lange, 85 U.S. (18 Wall.) 163 (1873); Bator 467-74.

16. See Frank v. Mangum, 237 U.S. 309 (1915); Bator 483-93.

17. See Waley v. Johnston, 316 U.S. 101 (1942); Johnston v. Zerbst, 304 U.S. 458 (1938); Bator 493-99.

18. These inatters are addressed at length elsewhere. See Wainwright v. Sykes, 433 U.S. 72, 79 (1977) (dictum); Bator 463-99; Developments 1042-56. For a concise history of the writ from its beginnings in twelfth-century England, see D. MEADOR, HABEAS CoRPus AND MAGNA CARTA (1966).

19. Townsend v. Sain, 372 U.S. 293, 327 (1963) (Stewart, J., dissenting).

20. Fay v. Noia, 372 U.S. 391, 402 (1963).

21. Stone v. Powell, 428 U.S. 465,492 n.31 (1976).

22. Friendly 157.

23. Fay v. Noia, 372 U.S. 391,441 (1963).

24. Id at 426; see Note, Federal Habeas Corpus for State Prisoners: The Isolation Principle, 39 N.Y.U. L. REv. 78, 78-81 (1964).

25. See, e.g., Kauffman v. United States, 394 U.S. 217, $231-42$ (1969) (Black, J., dissenting); Friendly; Bator. 
point here is that the Fay Court viewed habeas corpus not as a kind of appellate review but in its historical context as a relnedy for "persons whoin society has grievously wronged and for whoin belated liberation is little enough coinpensation." 26 Thus the Court did not repudiate but rather relied upon the historical conception of habeas. ${ }^{27}$

Other features of habeas are also difficult to reconcile with the conception of the habeas process as a quasi-appellate review. The custody requireinent, though inuch relaxed in recent years, still bars a prisoner from securing relief when there are insufficient legal restraints upon him. ${ }^{28}$ Underlying the custody requirement is the "personal nature" of the writ, "historically dedicated to the vindication of personal rights." 29 Unlike appeal, habeas corpus is a separate proceeding, and, therefore, the court is not bound by the record; it may hold a hearing and determine the facts for itself. ${ }^{30}$ The Fay decision also rests on these distinctive features of habeas corpus. Because habeas is a separate proceeding and the habeas court acts on the body of the prisoner instead of the judgment of the state court, a state procedural rule that would bar the assertion of a constitutional issue on appeal will not do so on habeas. ${ }^{31}$ " $[\mathrm{H}]$ abeas corpus cuts through all forms and goes to the very

26. 372 U.S. at 441 . Much of the opinion is given over to an elaborate treatment of the history of the writ, designed to show that the broad scope afforded habeas in Brown was consistent with its past. See id. at 399-426. See also HART \& WECHSLER 1465. The Court's performance as historian has drawn much criticism. See, e.g., Schneckloth v. Bustanonte, 412 U.S. 218, 253 (1973) (Powell, J., concurring); Fay v. Noia, 372 U.S. 391, 448-63 (1963) (Harlan, J., dissenting); Mayers, The Habeas Corpus Act of 1867: The Supreme Court as Legal Historian, 33 U. CHI. L. REv. 31 (1965); Oaks, Legal History in the High Court-Habeas Corpus, 64 MICH. L. REv. 451 (1966).

27. The reasoning of the Fay opinion must be carefully distinguished from the impact of its holding, as well as from the holdings in Brown and Jones. The Court's reasoning in Fay is consistent with the historical conception of the writ, but the effect of the holdings in these cases was to make habeas widely available, which in turn lent support to those, including members of the Court, who would characterize habeas as a kind of appellate review of state judgments. See text accompanying notes 11-12 supra.

28. See Gonzales v. Stover, 575 F.2d 827 (10th Cir. 1978); Wright v. Bailey, 544 F.2d 737 (4th Cir. 1976), cert. denied, 434 U.S. 825 (1977); Russell v. City of Pierre, 530 F.2d 791 (8th Cir.), cert. denied, 429 U.S. 855 (1976); $c f$. Naylor v. Superior Court, 558 F.2d 1363 (9th Cir. 1977) (writ denied; dismissed for mootness because the sentence had ended and there were no collateral consequences).

29. Schwartz v. Lennox, 320 F. Supp. 754, 756 (E.D. Pa. 1971) (writ unavailable to an estate for purposes of econounic gain); see Glen v. Hongisto, 438 F. Supp. 10, 12 n.1 (N.D. Cal. 1977) (because of its personal nature, writ unavailable to labor organization held in contempt of court).

The personal nature of the writ is also illustrated by its availability as a remedy for executive detentions that are wholly uncounected with judgments of civilian courts. See, e.g., Parker v. Levy, 417 U.S. 733 (1974) (writ deiried) (military); Bridges v. Wixon, 326 U.S. 135 (1945) (writ granted) (immigration). See generally Note, Servicemen in Civilian Courts, 76 YALE L.J. 380 (1976).

30. See Townsend v. Sain, 372 U.S. 293, 311-12 (1963).

31. See Fay v. Noia, 372 U.S. 391, 429-31 (1963). Of course, by freeing a prisoner held 
tissue of the structure. It comes in from the outside not in subordination to the proceedings. . .."32

The functional differences between habeas and direct review might be articulated in another manner. On appellate review, attention is focused on the proceedings below. ${ }^{33}$ The appeals court is bound by the record and inust reverse for any error that is not harmless. ${ }^{34}$ ln addition to correcting error, appellate review by the Supreme Court serves the purpose of enunciating uniform rules of national law. ${ }^{35}$ Habeas performs no such law-pronouncing function. ${ }^{36}$ Although the legality of the proceedings below might be at issue, the habeas court's focus is upon the prisoner; the question is whether the restraint upon him is so "extraordinary" or "intolerable" or so offends "basic justice" as to warrant his release.

If this standard is satisfied every time there is a constitutional violation in the petitioner's trial, then habeas corpus is most accurately described as a kind of appellate review. As a inatter of theory, habeas and appeal would remain distinct, but the theoretical distinction would be a quibble. In recent years, however, the Court has paid more attention to the historic function of habeas corpus and has attached less importance to expansive federal review of state judginents. In Stone $v$. Powell ${ }^{37}$ the Court held that fourth amendment claims may not be raised on a petition for habeas corpus if there was an opportunity for full and fair litigation of the claim in the state courts. The Court in Wainwright v. Sykes ${ }^{38}$ limited Fay, ruling that a prisoner must show "cause" for his failure to comply with a state procedural rule requiring that he make a contemporaneous objection to the imtroduction at trial of an improperly obtained confession and also that "prejudice" resulted from the use of the confession. ${ }^{39}$

These decisions reflect another distinctive feature of habeas

pursuant to a state court judgment, the grant of a petition for federal habeas corpus necessarily renders the state court judgment nugatory.

32. Frank v. Mangum, 237 U.S. 309, 346 (1915) (Holmes, J., dissenting).

33. See Mackey v. United States, 401 U.S. 667, 677-81 (1971) (Harlan, J., concurring and dissenting).

34. See Chapman v. California, 386 U.S. 18 (1967) (stating harmless error rule).

35. See The Federalist No. 82 (A. Hamilton) ("the national and State systeins are to be regarded as ONE WHOLE. The courts of the latter will of course be natural auxiliaries to the execution of the laws of the Union, and an appeal froin them will as naturally lie to that tribunal which is destined to unite and assimilate the principles of national justice and the rules of national decisions") (emphasis in original). See also Bator 453-54.

36. See Friendly 164-65. But cf. Cover \& Aleinikoff 1046-68 (discussing the shaping of new constitutional doctrine through habeas by the interaction of lower federal courts and state courts).

37. 428 U.S. 465 (1976).

38. 433 U.S. 72 (1977).

39. Id; see Francis v. Henderson, 425 U.S. 536 (1976) (cause and prejudice test applied to a 
corpus-the significant costs placed upon the states' interests in finality and federalism in controlling their criminal processes free from federal interference. Francis v. Henderson ${ }^{40}$ and Wainwright both emphasize the interest in federalism by assuring the integrity and effectiveness of state procedural rules. ${ }^{41}$ The Stone Court noted that while habeas does undercut the values of finality and federalism, such harn is acceptable when the claim relates to innocence, for then the historical function of habeas to remedy "intolerable restraints" and to do "basic justice" is served by hearing the petition; however, these costs should not be incurred when the prisoner inakes a fourth ainendment claim, where "a convicted defendant is usually asking society to redetermine an issue that has no bearing on the basic justice of his incarceration." 42

Stone, then, appears to be a retreat from the rulings in Brown and Fay that any constitutional defect in the proceedings leading to the petitioner's confinement enables the confinement to meet the standard of "intolerable restraint" or "affront to the conscience" that is requisite to relief on a habeas petition. In their place Stone announced an "innocence-related" standard as the contemporary articulation of the historical role of the writ to remedy extraordinary wrongs. ${ }^{43}$ The Stone opinion, in retreating from Brown and Fay on the standard for the

failure properly to assert a claim that the state's method for selecting grand jurors was constitutionally flawed).

40. 425 U.S. 536 (1976).

41. Wainwright, 433 U.S. at 88-90; Francis, 425 U.S. at 539-42.

42. 428 U.S. at 491 n. 31 ; see id. at 490 .

43. See Cover \& Aleinikoff 1069-72 for other indications that the Court will pursue an "innocence-related" standard in setting the scope of habeas. The two principles derived from Stone in the preceding paragraphs-that it is a retreat from Brown and Fay vis-à-vis the standard for cognizability of issues in habeas and that a proper standard is based on the relation of a claim to the prisoner's innocence-are based on a single footnote of a long opinion, 428 U.S. at 491 n.31. The text of the opinion is largely devoted to denonstrating that the fourth amendment exclusionary rule should not be applied in liabeas because its application there adds little to deterrence of illegal searches. See 428 U.S. at 482-96. But the two principles enunciated in footnote 31 have vitality beyond the fourth amendment context. See Cover \& Aleinikoff 1086-88; The Supreme Court, 1975 Term, 90 HARv. L. Rev. 1, 217-21 (1976). The Court itself has characterized Stone as a retreat from Brown, see Wainwright v. Sykes, 433 U.S. 72, 79 (1977), and several members of the Court have suggested other possible apphications of the Stone rationale, see Castaneda v. Partida, 430 U.S. 482, $508 \mathrm{n.l}$ (1977) (Powell, J., dissenting) ("Ia] strong case may be made that claims of grand jury discrimination are not cognizable on federal habeas corpus after Slone"); Brewer v. Williams, 430 U.S. 387, 420-29 (1977) (Burger, C.J., dissenting) (principles of Stone should apply to attempts to suppress reliable evidence obtained through unlawful custodial interrogation); Freeman v. Zahradnick, 429 U.S. 1111, 1111-16 (1977) (Stewart, J., dissenting to denial of certiorari) (Stone supports habeas review of the evidence under a reasonable doubt standard). See also Stone v. Powell, 428 U.S. 465, 502-15 (1976) (Brennan, J., dissenting) (explaining why Stone must be read as an interpretation of the habeas statute and not merely as a decision about the uses of the exclusionary rule); $i d$ at 517-18 (discussing possible applications of Stone to other rights). 
cognizability of issues in habeas and in asserting that a proper standard inust be grounded in the relation of a claim to the prisoner's innocence, inay be, as Justice Brennan said in his dissent, "a harbinger of future eviscerations of the habeas statutes." 44 But Justice Breman is hardly correct in claiming that " $[t]$ here is no foundation in the language or history of the habeas statutes for discriminating between types of constitutional transgressions." 45 Although the statutory language furnishes no such foundation, the Supreine Court has often distinguished ainong constitutional issues in habeas, ${ }^{46}$ and its decisions have not always expanded the range of issues that inay be raised. ${ }^{47}$

These aspects of Stone are important in considering the reasons why different habeas rules might be devised for free speech claims. They also reflect the more general principle that a habeas court, unlike an appellate tribunal, may differentiate among rights. This principle, rooted in the historic function of the writ to remedy confinements that were "affronts to the conscience" and "imtolerable restramts," was nearly forgotten in the years after Brown and Fay. Stone reaffirns the distinctive nature of the writ while opening the way for a more complex approach to habeas and, particularly, a more liberal approach to first amendment habeas.

Stone, Wainwright and Francis nay also signal the beginnings of a general cutback in the availability of collateral relief which could pose dangers for first amendment as well as procedural habeas. If the Court strongly values the interests of federalisin and finality that led to limits on habeas in these cases, it might decide to extend the Stone rule to all constitutional claims and thereby deny habeas whenever the issue has been fully and fairly considered im the state court. In view of this possibility it is imperative to identify the special features of free speech claims that would support an exception for these claims from any general cutback. The differences justifying a more liberal treatment of habeas clamis based on free speech as opposed to procedural grounds are addressed in Part II.

\section{The First Amendment/Criminal Procedure Dichotomy}

There are three reasons why free speech issues should be handled differently than procedural questions in habeas corpus. First, free speech rights are more closely connected to the ninocence standard

44. 428 U.S. at 516 (Brennan, J., dissenting).

45. Id. at 522 .

46. See Wainwright v. Sykes, 433 U.S. 72, $78-81$ (1977) (dictuin); Developments 1045-55. ring).

47. See Schneckloth v. Bustamonte, 412 U.S. 218, 250-58, $271-75$ (1973) (Powell, J., concur- 
enunciated in Stone than are procedural rights. Second, first amendment rights are particularly vulnerable to imsensitive state procedures, broadly worded state laws and the majoritarian pressures encountered by most state judges. The adequate defense of free speech rights may require a federal forum at some point, and a petition for habeas corpus is often the only means available for obtaining such a forum. Tlird, the finahity interests that work agaimst habeas are substantially weaker in the typical free speech case than im the typical criminal procedure case.

\section{A. Free Speech and the Basic Justice of the Prisoner's Incarceration.}

In its retreat from Brown and Fay, the Court im Stone identified the standard for grantimg habeas relief-that the prisoner suffer an imtolerable restramt or that lis imcarceration be contrary to basic justice-witlı the question of the prisoner's guilt or innocence. Because the fourth amendment exclusionary rule obstructs rather than aids the search for truth, sucli claims cannot be raised on habeas. Unlike the search and seizure claim advanced in Stone, rights such as the right to counsel or the right not to be convicted by use of a coerced confession help assure more accurate determinations of fact. Even so, they are not as closely connected to innocence as are first amendment claims. If a prisoner is released because the statute as applied to lis conduct violates the first amendment, it necessarily follows that he is innocent. If he is released on a procedural ground, however, it follows only that his rights have been violated; the determination of guilt or innocence must await a new trial. This difference between the consequences of a successful petition im a speech case and that im a procedure case warrants the conclusion that a first amendment habeas case bears more directly on innocence than does a procedural claim..$^{48}$

Two objections might be made to tlis analysis. The first, based on the presumption of innocence, can be disposed of with dispatch. Although a prisoner freed on a procedural ground is presumed innocent until proven guilty, he is not $\mathrm{m}$ the same position as the successful free speecl petitioner because he can still be found guilty of the crime at a later trial. The successful first amendment petitioner, on the otlier hand, cannot be found guilty.

The second and more significant objection is that the relationship of a constitutional right to the prisoner's innocence is not always an

48. Cf. Mackey v. United States, 401 U.S. 667, $689-93$ (1971) (Harlan, J., concurring and dissenting) (procedural/snbstantive distinction drawn with regard to prospective application of new rules in habeas). 
appropriate standard for evaluating whether a confinement meets the historical, and always elusive, habeas test of being an "intolerable restraint," or carrying a "connotation of outrage," or offending "basic justice." 49 Thus, there are procedural rights, such as the right against double jeopardy, that inay be asserted on direct appeal even by a concededly guilty defendant. ${ }^{50}$ A court may decide that im connection with those rights the "intolerable restraint" standard could be met even if the prisoner's claim were not related to innocence. ${ }^{51}$ The result of such a developinent, however, would not be to diminish the close connection between first ainendinent rights and the habeas standard. Innocence would probably reinain at the core of the habeas test, ${ }^{52}$ though the standard would likely becoine a bit more complex. ${ }^{53}$

The reason for drawing these distimctions between speech and procedural rights should not be misunderstood. The point is not that procedural claims are unrelated to the writ's function of remedying intolerable restraints on liberty. Rather, the argument is only that first amendment claims are more closely connected to that function than are procedural claims and therefore nay justifiably claim inore solicitude in habeas corpus proceedings.

\section{B. The Fragility of First Amendment Rights.}

The Supreine Court has surrounded the first ainendment with an array of protective devices designed to guarantee that free speech is not undermined by imprecise laws or by heavy-handed procedures. ${ }^{54}$ The

49. See text accompanying notes 19-23 supra.

50. See Menna v. New York, 423 U.S. 61 (1975) (per curiam).

51. See Greene v. Massey, 546 F.2d 51, 53 n.6 (5th Cir. 1977), rev'd on other grounds, 437 U.S. 19 (1978) (Stone not applicable to double jeopardy claim); Sedgwick v. Superior Court, 417 F. Supp. 386, 387 (D.D.C. 1976) (same); Cover \& Aleinikoff 1093-94.

52. The Court seems to be committed to innocence as the root of the habeas standard. See note 43 supra.

53. It should be noted that the issue whether the innocence standard is insufficiently complex does not turn solely upon the importance attached to constitutional values other than protecting the innocent. Even if it is agreed that innocence is "not the most fundamental imterest served by enforcement of constitutional claims," Wright \& Sofaer, supra note 1, at 907 n.43; see Stone v. Powell, 428 U.S. 465, 523-24 (1976) (Brennan, J., dissenting), the conclusion that non-innocence related values slrould be pursued in habeas does not nccessarily follow. The distinctions made earlier between rights and means of enforcing rights, see note 7 supra, and between the functions of habeas and appellate review, see text accompanying notes 13-36 supra, must be kept in mind. The function of habeas is not to defend all constitutional values, despite the importance of those values, but only to remedy egregious restraints on liberty. A tcnable arguinent can be made that a concededly guilty prisoner whose protection against double jeopardy has been violated is not subject to such a restraint. The inportant constitutional values at stake in a double jeopardy claim imight be adequately vindicated at trial, on appeal or in state babeas corpus proceedings.

54. See, e.g., Southeastern Promotions, Ltd. v. Conrad, 420 U.S. 546, 561 (1975); Bantam Books, Inc. v. Sullivan, 372 U.S. 58, 66 (1963); NAACP v. Button, 371 U.S. 415, $432-33$ (1963); 
premise behind these devices is that first amendment rights are "dehcate and vulnerable, as well as supremely precious to our society."5s Because "the line between unconditionally guaranteed speech and speech that may be legitimately regulated is a close one," "56 "the threat of sanctions may deter ... . [the exercise of first amendment rights] almost as potently as the actual application of sanctions," procedures may prove imsufficiently "sensitive" interests fully. ${ }^{59}$

For example, a law that properly regulates some expression nay sweep too broadly and proscribe protected as well as unprotected speech. In the ordinary run of cases a litigant may attack a statute only as it applies to him. ${ }^{60}$ However, when a statute is challenged on first amendment grounds, a litigant inay, in proper circumstances, assert the statute's overbreadth even if it is constitutional as applied to him. ${ }^{61}$ Moreover, the Court may strike down an overbroad law even if the governmental interest served by it outweighs the infringement of speech. ${ }^{62}$ The rationale for the doctrine is that the overbroad law might have a chilling effect on protected speech and consequently must be struck down at the first available opportumity. ${ }^{63}$ Another example of the Court's sensitivity to first amendment liberties is the rule that a court should inake an independent determination about the obscenity of offending materials, rather than deferring to the findings of a jury, a state court, a United States Magistrate or to a guilty plea. ${ }^{64}$

Speiser v. Randall, 357 U.S. 513, 525-26 (1958); Baldwin v. Redwood City, 540 F.2d 1360, 1374 (9th Cir. 1976), cert. denied, 431 U.S. 913 (1977).

55. NAACP v. Buttou, 371 U.S. 415, 433 (1963).

56. Southeastern Promotions, Ltd. v. Conrad, 420 U.S. 546, 561 (1975); see Bantam Books, Inc. v. Sullivan, 372 U.S. 58, 66 (1963) (the line is "dim and uncertain").

57. NAACP v. Button, 371 U.S. 415, 433 (1963); see Winters v. New York, 333 U.S. 507, 518 20 (1948); Thornhill v. Alabama, 310 U.S. 88, $97-98$ (1940).

58. Speiser v. Randall, 357 U.S. 513, 525 (1958). See also Monaghan, First Amendment "Due Process," 83 HARV. L. Rev. 518 (1970).

59. See, e.g., Baggett v. Bullitt, 377 U.S. 360, $378-79$ (1964); Bantam Books, lnc. v. Sullivan, 372 U.S. 58, 66-71 (1963); Marcus v. Search Warrant, 367 U.S. 717, 730-31 (1961); Smith v. California, 361 U.S. 147, 151-54 (1959).

60. See, e.g., United States v. Raines, 362 U.S. 17, 21 (1960).

61. E.g., Gooding v. Wilson, 405 U.S. 518, 520-21 (1972); Kunz v. New York, 340 U.S. 290 (1951).

62. See United States v. Robel, 389 U.S. 258, 268 n.20 (1967).

63. See First Amendment-Overbreadth 852-58.

64. See, e.g., Jenkins v. Georgia, 418 U.S. 153, 160 (1974) (making independent judgment on obscenity); Jacobellis v. Ohio, 378 U.S. 184, 188-90 (1964) (opinion of Brennan, J.) (independent judgment necessary in obscenity cases); Clicque v. United States, 514 F.2d 923 (5th Cir. 1975) (court must not accept guilty plea without imdependent review of materials to deterinime obscenity); McKinney v. Parsons, 488 F.2d 452 (5th Cir. 1974), appeal after remand, 513 F.2d 264, cert. denied, 423 U.S. 960 (1975) (court inust independently review materials and not merely accept 
First amendment habeas corpus should be viewed as related to these devices aimed at guaranteemg adequate protection for the freedom of speech. However, habeas differs from the other special protective devices for first amendment rights because it does not respond to a single, identifiable need. The chilling effect provokes the overbreadth doctrine; the bias or imsensitivity of jurors makes imdependent review necessary in obscenity cases. Broad habeas, on the other hand, reflects a judgment that as a general matter first amendment rights will be adequately protected only if free speech claims can be raised im an independent proceedimg before a federal court. Underlying this judgment is the perception that a federal court will hikely be more sympathetic to constitutional claims than the state courts ${ }^{65}$ and the proposition that there is less chance of an error resulting in a denial of constitutional rights when a claim is exannmed by two court systems than when it is heard by only one. ${ }^{66}$

These two principles have been advanced im support of broad availability of federal habeas corpus generally. The distinctive fragility of first amendment rights provides the justification for giving them increased protection im habeas proceedings. Procedural rights are not so delicate. A criminal defendant has a lawyer to tell him what his rights are and ordmarily has every mcentive either to exercise them or bargain them away for a favorable settleinent. ${ }^{67}$ Efforts by the state to inhibit the exercise of procedural rights are ordmarily visible enough to permit their correction at trial or on appeal. On the other hand, a person contenıplating the exercise of first amendinent rights $m$ a way that might run afoul of the criminal law, for example, by attending a mass demonstration or taping a peace symbol to a flag, faces a hard choice.

U.S. Magistrate's determmation of obscenity); Summerlin v. Sheriff, 350 F. Supp. 336, 339 (N.D. Ohio 1972) ("an entire line of lower federal courts seems to have adopted a standard of mandatory judicial review of obscenity questions"); Monaghan, supra note 58, at 526-32 (jury's role should be restricted in first amendment cases because "judges are less inclined to be affected by passion and prejudice and more inclined to realize the importance of first amendment values").

65. See Cover \& Aleinikoff 1045; Neuborne, The Myth of Parity, 90 Harv. L. Rev. 1105 (1977). But see Graves v. Estelle, 556 F.2d 743, 746 n.6 (5th Cir. 1977).

66. See Cover \& Aleinikoff $1045-46 \&$ n.60.

67. Procedural rights may soinetimes be inhibited by state practice, as when the state seeks a more severe sentence on reconviction following a successful appeal. The Court has recognized the dangers such practices may pose for the exercise of procedural rights. Compare North Carolina v. Pearce, 395 U.S. 711 (1969) (vindictiveness may not play a part in resentencing) with Chaffin v. Stynchcombe, 412 U.S. 17, 24-28 (1973) (higher sentence on retrial acceptable if jury not shown to be notivated by vindictiveness and did not know of prior sentence). The fact remains, however, that such inhibitions and efforts to remedy them are a relatively insignificant part of the law of crimimal procedure. Cf. Note, The Chilling Effect in Constitutional Law, 69 CoLUM. L. REv. 808, 832-33 (1969) (procedural rights seldom chilled); First Amendment-Overbreadth 852 n.33 ("overbreadth reasoning . . . is seldom encountered in cases involving the criminal process"). 
He must decide between the tranquility of daily life that could be maintained if lie foregoes the exercise of those rights and the possibility of arrest, the cost of bail and lawyer's fees, the consequences of a criminal conviction, the enmity of the community and otlier unpleasant implications of expressive activity. ${ }^{68}$ It may seem more prudent to forego the vigorous exercise of first amendment rights and to settle for more conventional, albeit less effective, modes of expression. ${ }^{69}$ This chill upon the exercise of free speecl cannot be directly remedied in the courts because the inhibited conduct never takes place and can never be tested in court. Indeed, the chill is effective precisely to the extent that it keeps individuals from going to court and fighting for their rights.

In addition to the contextual differences between the circumstances in which speech and procedural rights must be asserted, the institutional framework in which they must be vimdicated furtler justifies broader liabeas relief for first amendment claims. From the prisoner's standpoint, the great advantage of federal liabeas corpus is the opportunity to obtain an independent federal review of his state court conviction. The imstitutional differences between state and federal courts lead him, as they lead most litigants who claim that state officials have acted in violation of the federal constitution, to prefer a federal forum. But these institutional differences appear to provide more support for first amendment than for procedural habeas. In the habeas context, the relevant comparison is between the fedcral district courts and the state appellate courts, for these are the two tribunals that would review the work of the state trial court. The primary differcnce between the two is that federal judges are protected from majoritarian pressures while state judges are not. ${ }^{70}$ As a result, federal courts are

68. See, e.g., Amsterdam 800-02, 840-42; First Amendment-Overbreadth 854-55.

69. See, e.g., Cohen v. Cahfornia, 403 U.S. 15, 24-25 (1971) (expressive value of speech depends on its emotional as well as its cognitive elements); Terminiello v. Chicago, 337 U.S. 1, 4 (1949) (speech "may indeed best serve its high purpose when it induces a condition of unrest, creates dissatisfaction with conditions as they are, or even stirs people to anger"); $c f$. Ely, Flag Desecration: A Case Study in the Roles of Categorization and Balancing in First Amendment Analysis, 88 HARv. L. REv. 1482, 1489-90 (1975) (expression must be controversial to be most effective).

70. See Neuborne, supra note 65, at 1116 n.45, 1127-28. As Professor Neuborne points out, id. $1116 \mathrm{n} .45$, the other major difference between the federal habeas court and the state appellate court is that the habeas court may take evidence and redetermine the facts relating to the constitutional claim. See Townsend v. Sain, 372 U.S. 293 (1963). The importance of this feature of habeas is hard to measure. Compare Director, Administrative OfFice of United States Courts, ANN. Rep., Table C-4 at 313 (1977) (2.7\% of habeas cases go to trial) with Shapiro 336 (finding that some kind of evidentiary hearing was probably held in 33, or $12.8 \%$, of 257 Massachusetts habeas cases over a three-year period). It should be noted that many of the hearings included in Professor Shapiro's count were unrelated to the merits. See Shapiro 346-47 \& n.135 
likely to be more sympathetic to litigants presenting "issues which raise strong political passions"71 but may not prove superior in deciding more mundane questions.

Most criminal procedure issues arise in the course of routine trials. ${ }^{72}$ Only the rare case stirs much passion. ${ }^{73}$ In contrast, a criminal case concerning first ainendment rights will likely be highly publicized, for the defendant may be a purveyor of pornography, ${ }^{74}$ a flag desecrator $^{75}$ or a demonstrator. ${ }^{76}$ Often the very reason he is on trial is a result of or part of an effort to attract attention to himself or his cause, and the reason for his arrest unay be the community's disapproval of the ideas he expresses, while similar modes of expression by others go unchallenged. ${ }^{77}$ If majoritarian pressures ever influence judicial decisions, they will be more likely to do so in first amendinent cases than in criminal procedure cases. Broader first amendment habeas might be necessary to rectify errors resulting from those pressures. Persons may be inore likely to exercise their free speech rights (or what they believe to be their rights) if they can be sure that a state conviction may be challenged in a federal habeas court. Thus, the availability of broad

(one hearing solely concerned with procedural default), $350 \& \mathrm{n} .154$ (seven hearings on exhaustion of state remedies, two on bail and two on prison conditions or discipline). On habeas fact finding in free speech cases, see text accompanying notes 90-94 infra.

71. See Neuborne, supra note 65 , at 1128 .

72. Consequently, the state trial judge is likely to be well versed in constitutional criminal procedure. See Stone v. Powell, 428 U.S. 465, 493 n.35 (1976) (state courts have much expertise in adjudicating fourth aunendinent claims); Graves v. Estelle, 556 F.2d 743, 746 n.6 (5th Cir. 1977) ("the argument that federal judges are more expert in applying federal constitutional law is especially unpersuasive in the context of search-and-seizure claims, since they are dealt with on a daily basis by trial level judges in both systems").

73. See, e.g., Brewer v. Williams, 430 U.S. 387 (1977).

74. E.g., Amato v. Divime, 558 F.2d 364 (7th Cir. 1977); Wasserman v. Municipal Court, 543 F.2d 723 (9th Cir. 1976); McKinney v. Parsons, 513 F.2d 264 (5th Cir.), cert. denied, 423 U.S. 960 (1975); Orito v. Powers, 479 F.2d 435 (7th Cir. 1973); Hunt v. Keriakos, 428 F.2d 606 (Ist Cir.), eert. denied, 400 U.S. 929 (1970).

75. E.g., Smith v. Goguen, 415 U.S. 566 (1974); Royal v. Rockinghain County Superior Court, 531 F.2d 1084 (1st Cir.), cert. denied, 429 U.S. 867 (1976); Cline v. Rockingham County Superior Court, 502 F.2d 789 (1st Cir. 1974); Radich v. Criminal Court, 385 F. Supp. 165 (S.D.N.Y. 1974); Deeds v. Beto, 353 F. Supp. 840 (N.D. Tex. 1973).

76. E.g., Thompson v. Gaffney, 540 F.2d 251 (6th Cir. 1976), cert. denied, 429 U.S. 1078 (1977); Arbeitman v. District Court of Vernnont, 522 F.2d 1031 (2d Cir. 1976); Squire v. Pace, 516 F.2d 240 (4th Cir.), cert. denied, 423 U.S. 840 (1975); Smith v. Sheeter, 402 F. Supp. 624 (S.D. Ohio 1975); Severson v. Duff, 322 F. Supp. 4 (M.D. Fla. 1970).

77. See, e.g., Marks v. United States, 430 U.S. 188, 198 (1977) (Stevens, J., dissenting) ("my brief experience on the Court has persuaded me that grossly disparate treatunent of similar offenders is characteristic of criminal enforcement of obscenity law"); Sunith v. Goguen, 415 U.S. 566, 574-76 (1974) (discussing selective enforcement of flag desecration statutes); Squire v. Pace, $380 \mathrm{~F}$. Supp. 269, 277-78 (W.D. Va. 1974), aff'd, 516 F.2d 240 (4th Cir.), cert. denied, 423 U.S. 840 (1975) (discussing selective enforceinent of disorderly conduct statute); Amsterdam 800-01 ("the mayor and the chief of police . . . would never be arrested if they picketed a courthouse"). 
habeas in the free speech context can indirectly mitigate the distinctive fragility of first amendment rights.

\section{Federalism and Finality.}

The fragility of freedom of speech is reason enough to seek greater protection for speech rights than for criminal procedure rights im habeas, but it cannot alone justify different rules for first amendment claims. If the costs of first amendment habeas corpus hitigation were inordmate, expansion might be unwise and cutbacks warranted. In fact, however, the costs of first annendment habeas are less than the costs of procedural habeas. An examination of these costs supphes another justification for a distinctive and liberal treatment of first amendment habeas corpus petitions.

In Stone, the Court listed four societal values that are damaged by collateral attack. Two of these, "the most effective utilization of limited judicial resources" and "the necessity of finality in criminal trials,"78 may be deemed finality interests. The other two, "tlre minimization of friction between our federal and state systems of justice" and "tlie maintenance of the constitutional balance upon which the doctrine of federalisin is founded," 79 are interests of federalism. Some intrusion on federalism and finality interests is inevitable in any liabeas corpus litigation. But the damage to finahity is substantially less when first amendment issues are presented than when procedural claims are made. Federalism interests are furthered whenever habeas is limited, but federalism, taken alone, is not a strong basis for cutting the scope of liabeas in any context.

1. Finality. The interest in finality as a means of insuring the most effective utilization of limited judicial resources requires little explanation. "[П] a job can be well done once, it should not be done twice." 80 The point is not merely that relitigation costs money, but that it may waste "the intellectual, moral, and political resources involved in the legal system."81 Some of these resources are expended whenever issucs are relitigated in habeas. But when tlie prisoner is released on a substantive ground, as is true in first amendment cases, the costs do not include retrial..$^{82}$

78. 428 U.S. at 491 n.31 (quoting Schneckloth v. Bustamonte, 412 U.S. 218, 259 (1973) (Powell, J., concurring)).

79. 428 U.S. at 491 n.31.

80. Bator 451 .

81. Id.

82. See Mackey v. United States, 401 U.S. 667, 693 (1971) (Harlan, J., concurring and dissenting). 
"The necessity of finality in criminal trials" is a more subtle value. Finality is said to be essential to the effective operation of the criminal law. If crime is to be deterred, punishment must be certam and not tentative. If prisoners are to be reformed, they must at some point accept punishment and concentrate on becoming better citizens. The granting of broad habeas relief encourages prisoners to look backward at their trials and to deny (perhaps to themselves as well as to their jailors) the justice of their imprisonment. ${ }^{83}$

Another reason that finality is important rests on the msight that "[r]epose is a psychological necessity in a secure and active society." 84 Quite apart fron the need to help the prisoner to recognize that his incarceration is just, our procedural doctrines should "give us repose, ... enrbody the judgment that we have tried hard enough and thus may take it that justice has been done."85 Repose must be distinguished froin complacency. It is not the "snrug acceptance of injustice," but rather a refusal to fall victim to "unreasoned anxiety" that some error has been niade. ${ }^{86}$

Two other considerations also have been voiced. One is the practical difficulty of determining or redetermining facts in a habeas proceeding long after the events and of redetermining facts still later at a new trial. ${ }^{87}$ The other is that "[i]t must prejudice the occasional meritorious apphication to be buried in a flood of worthless ones." 88 Because so inany habeas corpus petitions are frivolous and because the volunie of habeas corpus petitions is great, the quality of consideration given each petition is diminished. According to Judge Friendly, this "nay be distasteful but no judge can honestly deny it is real."89

How strong are these interests in the first amendinent context? The last two can be disposed of in short order. First amendment cases rarely require the redetermination of facts. Sometimes the facts are disputed in a disorderly conduct case arising from a demonstration, ${ }^{90}$

83. See Schneckloth v. Bustamonte, 412 U.S. 218, 262 (1973) (Powell, J., concurring); Bator 452.

84. Bator 452.

85. Id.

86. Id. 453.

87. See Schneckloth v. Bustamonte, 412 U.S. 218, 261 (1973) (Powell, J., concurring) (quoting Amsterdam, Search, Seizure, and Section 2255: A Comment, 112 U. PA. L. REv. 378, 383-84 (1964)).

88. Brown v. Allen, 344 U.S. 443, 537 (1953) (Jackson, J., concurring).

89. Friendly 149.

90. Examination of forty-seven first amendment habeas cases reveals only one in which facts found in the state courts were relitigated. Raby v. Woods, 440 F.2d 478 (7th Cir. 1971). In that case a conviction for blocking traffic during the course of a demonstration was challenged on first amendment grounds. The district court held a hearing, redetermined the facts and grantcd the 
but the question more often is the constitutionality of a statute, either on its face ${ }^{91}$ or as applied to given conduct. ${ }^{92}$ For example, in obscenity cases the issue is the application of constitutional standards to materials held to be obscene by a state court. The habeas court may examine the materials ${ }^{93}$ and compare them with similar materials, the status of which has already been hitigated, ${ }^{94}$ but these procedures hardly create the practical fact-finding problems that give rise to concern. The possibility that meritorious petitions will get lost im the shuffle may be a reason for considering changes in habeas or for imcreasing the number of federal judges. But if first amendment claims otherwise merit distinctive treatment, they should be among the rights given most careful consideration under any habeas system.

The state's interest in repose and in the effective enforcement of its criminal law are powerful considerations militating agamst the broad availability of habeas corpus because so few habeas petitions are successful. It appears that under five percent of federal habeas petitions are granted. ${ }^{95}$ Doubtless even fewer prisoners actually wim release on

writ. The court of appeals reversed, criticizing the district court's "usurpation" of the jury's function. Id. at 482 .

Courts often hold evidentiary hearings in obscenity cases, but the purpose in such cases is to examme the offending material and compare it with other materials in order to make an independent judgment as to its obscenity under constitutional standards. See text accompanying notes 93-94 infra. Of course it is not entirely clear that the theoretical possibility of a factual hearing is of much practical significance even in procedural cases. See note 70 supra.

91. E.g., Gooding v. Wilson, 405 U.S. 518 (1972); Moore v. Newell, 548 F.2d 671 (6th Cir.), cert. denied, 431 U.S. 971 (1977); Walker v. Dillard, 523 F.2d 3 (4th Cir.), cert. denied, 423 U.S. 906 (1975); Wiegand v. Seaver, 504 F.2d 303 (5th Cir. 1974), cert. denied, 421 U.S. 924 (1975); Radford v. Webb, 446 F. Supp. 608 (W.D.N.C. 1978).

92. E.g., Smith v. Goguen, 415 U.S. 566 (1974); Hammond v. Adkisson, 536 F.2d 237 (8th Cir. 1976); Cline v. Rockingham County Superior Court, 502 F.2d 789 (1st Cir. 1974); Epton v. Nenna, 446 F.2d 363 (2d Cir.), cert. denied, 404 U.S. 948 (1971); Radich v. Criminal Court, 385 F. Supp. 165 (S.D.N.Y. 1974).

93. E.g., Wassernan v. Municipal Court, 543 F.2d 723 (9th Cir. 1976); McKinney v. Parsons, 513 F.2d 264 (5th Cir.), cert. denied, 423 U.S. 960 (1975); Wenzler v. Pitchess, 359 F.2d 402 (9th Cir. 1966), cert. denied, 388 U.S. 912 (1967); Sinnsson v. Spice, 390 F. Supp. 1271 (E.D. Wis. 1975); Summerlin v. Sheriff, 350 F. Supp. 336 (N.D. Ohio 1972).

94. E.g., Amato v. Divine, 558 F.2d 364, 365 n.2 (7th Cir. 1977); Hunt v. Keriakos, 428 F.2d 606, 607-08 (1st Cir.), cert. denied, 400 U.S. 929 (1970).

95. See, e.g., Director, Administrative OfFice of United States Courts, AnN. Rep. 132 (1971) (relief requested is not granted in $96 \%$ of habeas cases). Professor Shapiro conducted a three-year study of habeas in Massachusetts. "Of the 257 cases studied, 10 (less then 4\%) ended in an order effectively discharging the petitioner from custody." Shapiro 340 . For a number of other petitioners, "state conrt postconviction processes had gronnd to a halt and the federal petition was instrumental in getting thein started again." Id. 341. As he points out, habeas could serve this latter function without its present intrusiveness into state interests in finality and federalisin. See id. 369. Professor Shapiro's figures are for prisoners who were actually released. The Administrative Office's figures show only whether federal rehef was granted. The assumption that none of the prisoners was retried or reconvicted would of course be unwarranted. See Friendly 148 n.25. 
retrial. ${ }^{96}$ As an argument against the broad availability of federal habeas, the state's interest in repose is strengthened by these figures, for if habeas only rarely results in release, repose can hardly be attacked as a "smug acceptance of injustice," and the argument agamst repose takes on the character of "unreasoned anxiety."97 Similarly, if few prisoners are successful the state's imterest in effective enforcement of its criminal law and punishment of offenders takes on added weight. Habeas nay seein little more than a costly encumbrance that does no one much good.

First amendinent claims, however, are proportionately more successful than habeas corpus petitions im general. In Professor Shapiro's Massachusetts study, ten of 257 cases challenged the validity of statutes on their faces or as applied. Six of these were successful; four of the six were first amendinent cases. ${ }^{98}$ My review of forty-seven first amendment habeas cases decided since 1963 reveals that the petitioners were successful im twenty-one cases, or over forty-four percent. ${ }^{99}$ In virtually every one of these cases the court determined that the prisoner had to go free rather than that a procedural error had occurred and that a new trial had to be held. ${ }^{100}$ This striking success rate may be a reflection of

In any event, Judge Friendly and Judge Wright also report a success rate of less than five per cent. Id. 148 n.24; Wright \& Sofaer, supra note 1, at 899 n.16; see Fay v. Noia, 372 U.S. 391,440 n.45 (1963); Brown v. Allen, 344 U.S. 443, $498 \&$ n.11 (1953) (commenting on the low rate of success of habeas petitions). Also instructive is Professor Reitz's study of habeas in the 1950s. Reitz, Federal Habeas Corpus: Postconviction Remedy for State Prisoners, 108 U. PA. L. REv. 461, 481-513, 52532 (1960). Thirty-five successful petitions were discovered through a study of reported cases. Id. $481 \&$ n.112. Interestingly there is not a single first annendinent case anong thein. See id. 525-32.

96. See note 95 supra.

97. See text accompanying note 86 supra.

98. I derive these figures from Shapiro 331 (ten challenges based on "unconstitutionality of criminal statute, on its face or as applied"), id. 340 ("In 3 of the [successful] cases, it was held that the nuaterials on which obscenity convictions had been based were constitutionally protected") and id. $340 \mathrm{n} .103$ (citing three other successful challenges to statutes on their faces or as apphed, one of which, Goguen v. Smith, 471 F.2d 88 (1st Cir. 1972), aff'd, 415 U.S. 566 (1974), was a first amendment vagueness case).

99. The cases are collected in the Appendix, infra. Many habeas cases go unreported, doubtless sonie first amendinent cases among thein. It inight be argued that ny figures, based on the reported cases I have been able to find, are biased in favor of successful first annendinent petitions because a higher proportion of unsuccessful ones will be unreported. The validity of this argument cannot be determined in the absence of thorough examination of unreported cases. It is, however, noteworthy that one of Professor Shapiro's successful first amendinent habeas cases was unreported. See Shapiro 340 n.102. In addition, iny confidence in these figures is bolstered by their rough consistency with Shapiro's results. Although it is not clear from his report what percentage of free speech claims were successful, we do know that there were ten challenges to the vahidity of statutes. Six were successful, four of which were free speech cases. See note 98 supra and accompanying text. Assuming all four unsuccessful cases were also first amendinent attacks, the success rate in the Massachusetts study for free speech challenges to statutes would be fifty percent.

100. An exception is Hammond v. Adkisson, 536 F.2d 237 (8th Cir. 1976), where the state was 
the majoritarian pressures on state judges in emotionally charged, free speech cases. In light of these figures, repose and effective enforcement of the criminal law are dramatically weaker values im the first amendinent context. Repose becomes coinplacency in the state's denial of constitutional rights, and effective law enforcement often becomes enforcement of unconstitutional laws and punishment of innocent men.

In short, the hist of finality imterests developed by the opponents of broad habeas simply do not apply with inuch force to first amendment claims. The finahty argument derives its force fron the image it conjures of a prisoner who has been convicted of an ordinary crime that has no constitutional overtones and who is most likely guilty. Such a prisoner, however, is cognizant of the availability of habeas and is also aware that some of his guilty friends have been granted new trials after filing habeas petitions. Therefore, the prisoner avoids the "realization ... that he is justly subject to sanction, that he stands in need of rehabilitation." 101 Instead, he continues to "look back with the view to resurrectimg every imagmable basis for further hitigation." 102 The first amendment prisoner, on the other hand, is most likely a pornographer, a flag desecrator or a demonstrator. Many of these prisoners are asserting issues relatimg not to the procedural purity of their trials but to the constitutional immumity of their conduct, claims which are often successful. The substantially weakened position of finahty interests at stake in such cases supphes another element in the justification for an expansive approach to habeas in first amendment cases.

2. Federalism. The Court in Stone listed "the minimization of friction between our federal and state systems of justice" and "the maintenance of the constitutional balance upon which the doctrine of federalism is founded"103 as two societal values with which habeas conflicts. The Court also said it was unwilling to assume that state courts would not adequately protect constitutional rights. ${ }^{104}$ Earlier, concurring in Schneckloth v. Bustamonte, ${ }^{105}$ Justice Powell histed these same interests in federalism ${ }^{106}$ and said that the Court had "few more pressing responsibilities than to restore the mutual respect and the balanced

permitted to retry the prisoner under a proper constitutional standard. See Epton v. Nenna, 446 F.2d 363 (2d Cir.), cert. denied, 404 U.S. 948 (1971) (writ denied; successful attack on jury instruction presurnably would have resulted in new trial with proper instruction).

101. Bator 452.

102. Schneckloth v. Bustainonte, 412 U.S. 218, 262 (1973) (Powell, J., concurring).

103. 428 U.S. at 491 n.31 (quoting Schneckloth, 412 U.S. at 259 (Powell, J., concurring)).

104. 428 U.S. at $493-94$ n.35; accord, Graves v. Estelle, 556 F.2d 743, 746 n.6 (5th Cir. 1977).

105. 412 U.S. 218 (1973).

106. Id. at 259 (Powell, J., concurring). 
sharing of responsibility between the state and federal courts."107 The Court could help achieve that goal "without retreat from our inherited insistence that the writ of habeas corpus retain its full vitahity as a means of redressing mjustice" by refusing to entertain fourth amendment habeas claims. ${ }^{108}$

The goals of minimizing friction between federal and state courts and of assuring that they share the responsibility for guaranteeing rights would be served by restrictions on first amendment habeas just as they are by cutbacks in the cognizability of fourth amendment or other constitutional rights. Accordingly, there is no poimt im attempting to draw distinctions between free speech and other rights with regard to federalisin. It should be noted, however, that the federahism arguinent for restrictive habeas is not strong. The requirement that a prisoner exhaust state remedies before petitioning for federal habeas assures that the state will have an opportunity to enforce its laws and adjudicate the constitutional issues in a case before the federal courts enter the controversy. In this connection a useful contrast can be drawn between habeas corpus and injunctive rehef. The Supreme Court has severely restricted the availability of injunctive rehef against pending state prosecutions on the ground that, save the rare case where the state prosecution is in bad faith, "Our Federalism" demands that states be permitted to enforce the criminal law without such imterference. ${ }^{109}$ At the same time, courts have soinetimes pointed to the availability of habeas relief after state proceedings have run their course as a less intrusive federal remedy than mjunctive relief for asserted violations of constitutional rights. ${ }^{10}$

The positioning of liabeas relief after rather than before state proceedings is related to another consideration that diminislies the force of the federahism argument. Because state courts are guaranteed the first opportunity to hear a prisoner's constitutional claims and because they are not bound by the decisions of lower federal courts in habeas cases, they retain a substantial role im defining and enforcing constitutional rights. They can refuse to follow the decisions of those courts or can follow thein only narrowly. Their responses may influence future federal court decisions. This dialogue between state and lower federal

107. Id. at 265 (Powell, J., concurring).

108. Id.

109. Yonnger v. Harris, 401 U.S. 37, 44 (1971).

110. See, e.g., Stone v. Powell, 428 U.S. 465, 513 n.10 (1976) (Brennan, J., dissenting); O'Shea v. Littleton, 414 U.S. 488, 502 (1974); Porter v. Kimzey, 309 F. Supp. 993, 994 n.l (N.D. Ga), aff'd, 401 U.S. 985 (1970); Scott v. District Attorney, 309 F. Supp. 833, 835 n.4 (E.D. La. 1970), aff'd, 437 F.2d 500 (5th Cir. 1971). 
courts has been dubbed "dialectical federalism."111

There is one final objection to using federalism as a major factor in limiting the scope of habeas. Because any restrictions on habeas would tend to minimize friction and preserve the balance between the state and federal systems, the use of federahsm as the sole criterion does not provide for any limitations upon its use. Taken to its logical conclusion it seems to require that no constitutional claim be cognizable in liabeas so long as the state court has given it a fair hearing. ${ }^{112}$ The Supreme Court inay not be willing to go that far in reshaping liabeas. ${ }^{113}$ But as the test itself seems limitless, it is impossible to tell from one case to the next just how it will affect the outcoine. The danger is that courts will use federalism as a screen behind which other-perhaps illegitimate-reasons lurk, just as courts today sometimes seein to use the vague abstention standards- -uncertainty of state law" and "difficult constitutional question"- to rationalize abstention decisions that actually are based on the courts' preferred results on the merits. ${ }^{14}$ It seems justifiable to conclude that, while free speech claims cannot be distinguished froin other habeas claims in terins of intrusions on the interest in federahism, that interest unalloyed with finality or other considerations militating against habeas is not a strong rationale for limiting the availability of the writ in any context.

\section{The SCOPE of First Amendment Habeas}

If the different functions of habeas and appellate review permit the habeas court to handle some constitutional rights witl greater solicitude than others, and if free speech issues can lay claim to more liberal treatment than procedural rights receive, the remaining question that requires attention is what distinctive rules and principles might be appropriate in the first amendment context.

\section{A. The Cognizability of First Amendment Issues on Habeas.}

The Court's recent decisions in Wainwright, Francis and Stone, cutting back the scope of the writ im pursuit of countervailing values of finahty and federalism, suggest that further limits upon habeas may be forthcoming. In particular, the Stone rule, barring fourtli amendment claims where the state courts provide a fair opportumity to litigate them,

111. See Cover \& Aleinikoff 1046-68.

112. See The Supreme Court, supra note 43 , at 217-18.

113. But see text accompanying notes 116-24 infra.

114. See Field, The Abstention Doctrine Today, 125 U. PA. L. Rev. 590, 602 \& nn.51-52 (1977); Field, Abstention in Constitutional Cases: The Scope of the Pullman Abstention Doctrine, $122 \mathrm{U}$. PA. L. REV. 1071, 1135 \& n.167 (1974). 
may foreshadow more general limits on the cognizability of claims on petitions for habeas corpus. Should the Court extend Stone to other constitutional claims, the distinctions drawn in Part II of this Article between speech and procedural habeas would support the retention of full review of first anendinent issues even if habeas review is restricted for procedural questions.

The practical sigmificance of this point may be questioned. Certainly the "innocence" standard intimated in Stone would rarely pose a threat to first aunendment claims. ${ }^{115}$ There are, however, periodic efforts in Congress to anend the habeas statute to provide for review only when the state courts have failed fairly to consider a constitutional claim. ${ }^{116}$ In addition, the innocence standard may prove unstable, and Stone may be remeinbered not as the case that laid down an innocence standard for determining whether an issue may be raised on habeas, but as the case that began an effort by the Supreine Court to himit the issues that may be raised.

Why inay the innocence standard be unstable? As stated in Stone, that standard would likely bar claims that obstruct the truth-finding process, such as an assertion that Miranda warnings should have been given in cases where the confession is concededly rehable. ${ }^{117}$ It might also apply to "truth-neutral" rights, such as double jeopardy and denial of speedy trial, which operate to prevent prosecution of the defendant regardless of his guilt or innocence. ${ }^{118}$ Extension to these claims should not be presuined too quickly, however. Such rights "contrast with the exclusionary rule which merely blocks one avenue of proof but does not alter our normal conception that this defendant, if guilty, should be convicted." 119 In addition, even a Miranda clain can be related to the

115. First amendment overbreadth claims would likely be an exception to this generalization. See text accompanying notes 193-219 infra.

116. See, e.g., H.R. 5649, 84th Cong., 1st Sess., 101 CoNG. REc. 4747 (1955); S. 917, 90th Cong., 2d Sess., 114 Cong. Rec. 11189 (1968); S. 567, 93d Cong., 1st Sess., 119 Cong. Rec. 2221 (1973), all of which are discussed in Note, Relieving the Habeas Corpus Burden: $A$ Jurisdictional Remedy, 63 lowa L. Rev. 392, 403-05 (1977). See also Note, Proposed Modification of Federal Habeas Corpus for Prisoners-Reform or Revocation?, 61 GEo. L.J. 1221 (1973).

117. See Richardson v. Stone, 421 F. Supp. 577 (N.D. Cal. 1976) (Sione applies to Miranda claim); cf. Brewer v. Williams, 430 U.S. 387, 420-29 (1977) (Burger, C.J., dissenting) (Stone should apply to claim of denial of right to counsel during custodial interrogation, where the evidence is reliable).

118. But see Greene v. Massey, 546 F.2d 51, 53 n.6 (5th Cir. 1977), rev'd on other grounds, 437 U.S. 19 (1978) (Stone not applicable to double jeopardy claim); Sedgwick v. Superior Court, 417 F. Supp. 386, 387-88 (D.D.C. 1976) (same). Of course, double jeopardy and speedy trial rights can also safeguard the accuracy of the guilt-determming process by banning the use of stale evidence and barring the prosecution from taking unfair advantage of the laws of probability through repeated trials.

119. Cover \& Alemikoff 1093. 
accuracy of the guilt-determining process, because it may form the basis for a claim that the confession was coerced. Though district courts applying the standard may be able without too nuch trouble to draw the necessary line between evidence of a Miranda violation and evidence of coercion, they can hardly avoid addressing the petitions in the first place. A prisoner with a Miranda claim would simply take care to assert that the error impinged on the guilt-determining process. The number of habeas petitions would not decline nuch, and most of the harm to values of finality and federalisin would remain. ${ }^{120}$

The logic of the "guilt-innocence" inquiry could even lead to the expansion of habeas. At present a habeas court will review the evidence only to determine whether "any" evidence exists to support the conviction-not whether the constitutionally mandated "reasonable doubt" standard has been met. ${ }^{121}$ But such limited review of the evidence is difficult to reconcile with the premise that the purpose of habeas is to assure that innocent persons are not imprisoned. ${ }^{122} \mathrm{Ex}-$ panded review of evidence would, of course, further intrude upon the finality and federahsm interests that so impressed the Court in Stone, Wainwright and Francis.

If the Court is sufficiently committed to strengthering those values, it will be unsatisfied with an innocence standard that may increase the costs of habeas and that certainly will not dimimish them significantly. And if it is strongly committed to the proposition that state courts are adequate protectors of federal rights, the logic of its convictions may well drive it to overrule Brown and revert to Frank $v$. Mangum, ${ }^{123}$ which held that no claim may be heard on habeas unless

120. As is readily apparent from the low success rate of habeas applications, see note 95 supra and accompanying text, the costs of habeas are best measured not in terms of the small number of prisoners released but in terms of the large numbers of petitions filed. If, in its application to other rights, Stone merely results in a recasting of habeas petitions to allege some defect in the guiltdetermining process it will have little impact on the number of petitions filed. $C f$. Cover \& Aleinikoff 1078-86; Rosenberg, Jettisoning Fay v. Noia: Procedural Defaults by Reasonably Incompetent Counsel, 62 MinN. L. Rev. 341, 430-39, 448 (1978) (both articles suggest that the Court's strict standard for procedural default enunciated in Wainwright v. Sykes, 433 U.S. 72 (1977), will result in more claims of ineffective assistance of counsel).

121. See Thompson v. City of Louisville, 362 U.S. 199 (1960); McLindon v. Warden, 575 F.2d 108, 111 (7th Cir. 1978).

122. See Freeman v. Zahradnick, 429 U.S. 1111, 1111-16 (1977) (Stewart, J., dissenting to derial of certiorari):

[A] federal habeas court asked to determine whether the evidence in a state prosecution was sufficient would be discharging the principal function underlying its jurisdiction-determming whether a defendant's custody is in violation of federal constitutional law. And the question whether a defendant has been convicted without sufficient cause is hardly irrelevant to innocence. Cf. Stone v. Powell, 428 U.S. 465 [(1976)].

429 U.S. at 1115; see Cover \& Aleinikoff 1095-1100.

123. 237 U.S. 309 (1915). 
the state court lacked jurisdiction or failed fairly to consider the issue. ${ }^{124}$

The prospect is not farfetched. The Court has already "limited" Fay, ${ }^{125}$ the cornerstone of modern habeas law, and Brown would be an easy target on technical grounds. The opinions im Brown merely asserted that habeas corpus was available for all constitutional claims and cited the statute. ${ }^{126}$ The Court did not explaim why the statute was being read differently from past interpretations. ${ }^{127}$ Fay supphed a historical and theoretical rationale for Brown. But this dictum from Fay may be considered less persuasive now that Fay has been questioned on the issue of procedural default. If Brown were overruled, the Court inight well be persuaded that the costs of habeas to finahity imterests apphed equally regardless of the nature of the right asserted by the petition. ${ }^{128}$ The discussion in Part II was an effort to show not only that this conclusion is unwarranted, but also that there are other reasons-the close cormection of speech claims to the historical function of the writ and the distinctive fragility of freedom of speech-for carving out an exception for free speech claims. ${ }^{129}$ Accordingly, first amendment claims should remaim fully cognizable on petitions for habeas corpus even if review of other claims is hinited to issues not fairly considered by the state court.

\section{B. Free Speech and the Incidents of Habeas: Prospectivity, Custody, Exhaustion and Procedural Default.}

1. General Considerations. A writ of habeas corpus will not is-

124. See Bator 483-93.

125. See Wainwright v. Sykes, 433 U.S. at 72, 85 (1977).

126. 344 U.S. at 447,464 (opinion of Reed, J.); id. at 500, 507-08, 513 (opinion of Frankfurter, J.).

127. Bator $500-01$.

128. This is the assumption of Professor Bator throughout his article. See Slone, 428 U.S. at 522-23 (Brennan, J., dissenting); The Supreme Court, supra note 43, at 217 ("The general costs of federal habeas corpus review noted by the [Stone] Court . . . apply with equal force in all habeas cases" (citation omitted)).

129. It may be argued that simce a general return to Frank would abandon the Stone "innocence-related" standard, first amendment clainis could no longer rely on their close connection with innocence as a basis for preferred treatment. But rejecting the Stone test in favor of something more restrictive does not require that the Court reach that conclusion. In recognition of the historical role of the writ to rennedy intolerable restraints and do basic justice, and the preinise that confineinent of an innocent person is perhaps the best example of an intolerable restraint, the Court could nake an exception for clainis, such as most first amendinent challenges, whose vindication would necessarily result in a finding that the prisoner was innocent. It is noteworthy that habeas for federal prisoners has been available for attacking the constitutionality of the statute nnderlying the conviction as far back as Ex parte Siebold, 100 U.S. 371 (1879). See Amsterdam, supra note 87 , at 384 n.30. 
sue unless the petitioner is in custody, has exhausted his state remedies and has not committed an inexcusable procedural default in the state courts. Moreover, a change in constitutional law may or may not be inade available to persons placed in custody and tried before the change. In this section the rules governing these inatters are examined. In some instances the rules already in effect implicitly recognize the distinctiveness of first amendment habeas. It is suggested that other rules might justifiably be recast in order to better accommodate free speech claims.

These incidents of habeas will be discussed in terms of the criteria developed in Part II. The close relationship of free speech claims to the function of the writ to remedy unjust restraints on liberty ${ }^{130}$ and the fragility of first amendment rights ${ }^{131}$ support nore liberal rules for those rights witl regard to the incidents of habeas. The lesser intrusions of first amendment liabeas upon finality interests ${ }^{132}$ and the weakness of a broad federalist interest in avoiding any federal interference with state criminal processes ${ }^{133}$ generally support inore relaxed rules.

Since different values are involved to different degrees in the various incidents of labeas corpus, the state interests in finality and in federalism are stronger arguments for giving a limited scope to some incidents of habeas than to others. For example, the restrictive rules on exhaustion of state remedies and on procedural default reflect a concrete interest in maintaimg the integrity of the state's trial and appellate processes and not inerely the Stone Court's protean interest in limitimg all collateral federal intrusions into the state criminal adjudication process. Similarly, the state's finality interest is stronger when the issue is whether a new constitutional standard should be applied retroactively in habeas to free a prisoner confined pursuant to a conviction that was free of error when rendered.

2. Prospectivity. The prospectivity issue is posed by a hypothetical case: $A$ and $B$ are convicted of crimes. After $A$ 's conviction is final but while $B$ 's case is still on appeal, the Supreme Court makes a new rule of constitutional law that would render both convictions invalid. The new rule will apply on $B$ 's appeal. $A$ files a habeas petition, claiming he should be released under the new standard.

Should the new rule apply to this case? Two courts of appeals recently addressed this issue in the course of deciding obscenity labeas

130. See text accoinpanying notes 48-53 supra.

131. See text accoinpanying notes 54-69 supra.

132. See text accompanying notes 80-102 supra.

133. See text accompanying notes 103-14 supra. 
cases that were tried under the Roth-Memoirs test. ${ }^{134}$ The prospectivity issue, important to the reasoning but not strictly necessary to the decision of either case, was whether the habeas petitioner should be given the benefit, if any, of the Supreme Court's latest rulings on obscenity announced in Miller v. California. ${ }^{135}$ In other decisions the Court had said that on direct appeal defendants would be given the benefit of the new standards. ${ }^{136}$ In McKinney v. Parsons, ${ }^{137}$ the Fifth Circuit stated that "in the spirit" of those rulings, it would extend the benefit of the new rules to habeas petitions. In Amato v. Divine, ${ }^{138}$ the Seventh Circuit pointed out that the Supreme Court, in holding the new rules effective on direct appeal, had emphasized that new rules customarily were applied on appellate review. The Amato court drew the imference that the benefit of the new rules should not extend to habeas petitions. ${ }^{139}$

The Amato court was right in concluding that new rules applicable on direct review need not be extended to habeas petitions. The functional differences between collateral attack and appeal, as well as the intrusions of habeas upon values of federahsm and finahty, support a different approach to prospectivity in the habeas context. ${ }^{140}$ As a practical matter, restricting a new holding to prospective application on habeas would avoid use of the rule to release large numbers of prisoners whose trials were held years before the new decision was announced, a point that might make it easier for the new rule to gain wide acceptance. But the court's further dictum that a new first amendment ruling would not apply in a habeas corpus proceeding neglects the close relation of first ainendment (and other substantive) rights to the basic justice of the prisoner's incarceration as well as the lesser finality costs

134. Memoirs v. Massachusetts, 383 U.S. 413 (1966); Roth v. United States, 354 U.S. 476 (1957). See generally Kalven, The Metaphysics of the Law of Obscenity, 1960 SUPREME COURT Rev. 1; Note, More Ado About Dirty Books, 75 Y ALE L.J. 1364 (1966).

135. 413 U.S. 15 (1973).

136. See Hamling v. United States, 418 U.S. 87, 102 (1974); Marks v. United States, 430 U.S. 188, 196-97 (1977).

137. 513 F.2d 264, 268 (5th Cir. 1975); cf. United States ex rel. Williams v. Preiser, 497 F.2d 337, 339 (2d Cir.), cert. denied, 419 U.S. 1058 (1974) (holding that a new constitutional rule limiting state regulation of abortion would be applied to free habeas petitioner convicted before the new decision).

In Wasserman v. Municipal Court, 543 F.2d 723 (9th Cir. 1976), the court held that the Miller test should be applied even when it diminishes constitutional protection. The decision is plamly incorrect, as a person could not have fair warning at the time of his acts that the Roth-Menoirs test would later be inade more restrictive. See Marks v. United States, 430 U.S. 188 (1977) (direct appeal). That Wasserman arose in habeas is irrelevant to the issue of fair warning.

138. 558 F.2d 364 (7th Cir. 1977).

139. Id. at 365 .

140. Perhaps the inost forceful statements of this position are to be found in Justice Harlan's concurring and dissenting opinion in Mackey v. United States, 401 U.S. 667, 675-702 (1971) and in Mishkin, Foreword: The High Court, The Great Writ, and the Due Process of Time and Law, 79 HARV. L. REv. 56, 77-102 (1965). 
where first amendment rights are at issue. A new procedural rule may bear only a tenous relationship to the prisoner's guilt or innocence and the justice of his incarceration. The costs to finality may be too great to warrant its apphication to his case. ${ }^{141}$ But a new substantive rule "represents the clearest instance where finality interests should yield." $142 \mathrm{Be}-$ cause a man confined pursuant to a now invalid substantive rule is unquestionably innocent under current standards, his mcarceration is indisputably contrary to basic justice. In addition, "issuance of the writ on substantive due process grounds entails none of the adverse collateral consequences of retrial," ${ }^{143}$ such as expenditure of resources and difficulties in rehitigating the factual guilt or innocence of the defendant, that often add to finality costs in the procedural context. The McKinney rule, applying new holdings retroactively in free speech cases when they benefit the petitioner, recognizes these distinctive features of first amendment habeas and seems the better approach to the retroactivity question.

3. Custody. In its early days the whole function of the writ of habeas corpus was to require the respondent jailor to produce his prisoner before the court. ${ }^{144}$ It was the incarceration of persons without legal cause that inspired the transformation of habeas from "a procedural device to facilitate inedieval hitigation" 145 into "the best remedy available for those who considered that they had been unlawfully imprisoned by the crown." 146 It is the tangible restraimt placed on liberty by prison walls that led Professor Chafee to describe habeas as "the most important human right in the constitution." 147 Yet the custody requirement has grown steadily more attenuated in the last twenty years.

At one time the custody requirement was met only by "tangible physical restraints." 148 Confinement to the city limits, ${ }^{149}$ or release.on bail, ${ }^{150}$ on parole, ${ }^{151}$ or on probation was not sufficient. Nor was the

141. See Mackey v. Unitcd States, 401 U.S. 667, 692 (1971) (Harlan, J., concurring and dissenting).

142. Id. at 693 .

143. Id.

144. See Fay, 372 U.S. at 402; Developments 1072.

145. D. MEADOR, supra note 18, at 3.

146. 9 W. HOLDSWORTH, A HistoRY OF ENGLish LAW 114 (1938).

147. Chafee, The Most Important Human Right in the Constitution, 32 B.U.L. REv. 143, 143 (1952).

148. Developments 1073.

149. See Wales v. Whitney, 114 U.S. 564 (1885).

150. See Stallings v. Splain, 253 U.S. 339 (1920).

151. See Weber v. Squier, 315 U.S. 810 (1942) (denying certiorari on grounds of mootness). 
writ available after a jail sentence had expired. ${ }^{152}$ In recent years, however, the Court has held that physical restraint is not necessary for habeas jurisdiction. Prisoners on parole ${ }^{153}$ or released on their own recognizance awaiting execution of sentence ${ }^{154}$ have been deemed to be "in custody." If an application for habeas is made while the prisoner is in custody, the case is not mooted by his subsequent unconditional release if there remain sufficient collateral consequences of his conviction. ${ }^{155}$

The historical function of the custody requirement was to distmguish those restraints on liberty deemed serious enough to warrant the extraordinary relief afforded by habeas. The Court's recent decisions signal the abandonment of that ancient role. ${ }^{156}$ Yet courts have contimued to apply the custody rule where even minimal restramts are not present. In recent first ainendment cases, for example, a fifty dollar fine, a twenty-five dollar fine and a lack of collateral consequences following coinpletion of a sentence were deemed insufficient to ineet the custody requirement. ${ }^{157}$ The courts' refusal to abandon the remnants of the custody requirement ${ }^{158}$ even though it no longer performs its original function is due to their reluctance to empty the statutory language of its last bit of content. In view of the Supreme Court's consistent refusal to permit the habeas statutes to interfere with its own judgments about the proper scope of habeas, this concern seems misplaced. ${ }^{159}$

There may be another reason for the tenacity of the custody requirement. That rule is not historically or logically connected with

152. See Parker v. Ellis, 362 U.S. 574 (1960) (per curiam).

153. See Jones v. Cunningham, 371 U.S. 236 (1963).

154. See Hensley v. Municipal Court, 411 U.S. 345 (1973).

155. Carafas v. LaVallee, 391 U.S. 234 (1968). See generally Developments 1074-79.

156. See Hensley v. Municipal Court, 411 U.S. 345, $353-54$ (1973) (Blackmun, J., concurring in the result); $c$. HART \& WECHSLER 1508 (once physical restraint is abandoned as the test for custody it may be impossible to draw ineaningful distinctions between custody and no-custody situations). The break with history is discussed in Oaks, supra note 26, at 468-72.

157. Naylor v. Superior Court, 558 F.2d 1363 (9th Cir. 1977) (writ denied for mootness because sentence ended with insufficient collateral consequences); Wright v. Bailey, 544 F.2d 737 (4th Cir. 1976), cert. denied, 434 U.S. 825 (1977) (\$50 fine); Russell v. City of Pierre, 530 F.2d 791 (8th Cir.), cert. denied, 429 U.S. 855 (1976) (\$25 fine).

158. See, e.g., Gonzales v. Stover, 575 F.2d 827 (10th Cir. 1978) (fugitive not in "custody" and therefore may not petition for habeas corpus).

159. See Wainwright v. Sykes, 433 U.S. 72, 79-81 (1977) (dictum); Developments 1072. The Court's readimess to interpret the habeas statute as it pleases also furnishes the answer to the objection that since custody is a statutory requirement, the Court may not set different standards of custody for different rights. Thus, under the statute the writ extends to all prisoners "in custody in violation of the Constitution." 28 U.S.C. \& 2241(c)(3) (1976). Under Stone, the content of the latter five words seemingly depends on the constitutional right at issue. Surely the first two words should be capable of similar flexibility. 
finality and federalism. In the century or so that the writ lias been available to attack the judgments of courts of competent jurisdiction, however, the requirement has served to restrict the use of the writ for the purpose of attacking such judgments and thereby has somewhat limited the intrusions of habeas upon those imterests. Perhaps the contemporary custody rule is best viewed as a means of providimg an extra measure of protection for finality and federahsm. If so, then there are grounds for distinguishing first ainendment froin procedural habeas. Not only are the costs to those values minimal in the free speech context, but the fragility of first amendment rights and their close connection to the writ's historical role of doing basic justice are also strong counterweights to the values of finahty and federahsm. In view of these considerations, a persuasive argument can be made that the custody requirement should be met by conviction alone in the first amendinent context. ${ }^{160}$

4. Exhaustion. In contrast to custody, the requirement of exhaustion was a relative latecomer to the law of habeas corpus. Not until 1886, in Ex parte Royall, ${ }^{161}$ did the Court require a prisoner to exhaust state remedies before he could assert his clanns on federal habeas. The explanation for the Royall rule is straightforward. There was no federal habeas for state prisoners until the Habeas Corpus Act of $1867 .{ }^{162}$ In addition, so long as habeas courts considered only the validity of executive detention and the jurisdictional competency of committing courts, there was no occasion to exannine prisoners' claims that their constitutional rights had been violated. Since the federal court would not address these issues on a petition for habeas corpus anyway, it made no difference whether a state court had done so. But when the Court began to hear constitutional clanns on their merits, some state criminal defendants sought to circumvent state criminal processes by filing habeas applications before trial or appeal. ${ }^{163}$ In order to avoid "unnecessary conflict[s] between courts equally bound to guard and protect rights secured by the Constitution,"164 the exhaus-

160. Cf. Cantrell v. Folsom, 332 F. Supp. 767 (M.D. Fla. 1971). This case began when habeas proceedings were brought in federal court. The city then moved in state court to vacate the convictions, apparently for the purpose of blocking federal court adjudication of the constitutionality of the vagrancy ordmance under which the convictions had been obtained. The district court, finding there was a threat of future prosecutions, permitted the petitioners to proceed as a class for a declaration that the statute was invalid. Their suit was successful.

161. 117 U.S. 241 (1886). See generally Developments 1093-1103.

162. Act of Feb. 5, 1867, ch. 27, 14 Stat. 385. See generally Mayers, supra note 26.

163. See, e.g., Hillegas v. Sams, 349 F.2d 859, 861 (5th Cir. 1965) (concurring opinion), cert. denied, 383 U.S. 928 (1966); Amsterdam 884-88.

164. Ex parte Royall, 117 U.S. 241, 251 (1886). 
tion requirement was instituted.

The exhaustion requirement, then, is a way of protecting the concrete intercst of fcderalisin in the integrity and effectiveness of state criminal and appellate processes ${ }^{165}$ and is unrelated to the nature and purposes of the writ. ${ }^{166}$ It guarantccs that states will be able to administer their criminal laws without interference from the federal courts prior to the termination of the state adjudication process. The price of this concession to federalisin is paid by the prisoner. Federal attention to his claim is delayed, and imvalid confineinent may be prolonged. ${ }^{167}$ This imterest of federalism in maintaining the effectiveness and integrity of state criminal processes is more compelling than the Stone Court's mutable federalist interest in avoiding any intervention. As a result, the case for maintaining a strict exhaustion requirement even in first amendinent cases may be stronger than it is for maintaining strict rules in cormection with cognizability, custody or prospectivity.

Because of the fragility of first amendment rights, it has been argued that exhaustion should not be required in free speech cases, ${ }^{168}$ especially where the state prosecution might intimidate others from exercising their first amendment rights. ${ }^{169}$ In such cases, federal habeas would be available to test the constitutionality of the statutc, on its face or as applied, before the state trial. Deciding the inerits of this proposal entails a choice of values between the more secure protcction of first anendment rights achieved by lifting the exhaustion requireinent and the state imterest im administering the criminal law and adjudicating constitutional claims in its own courts before federal imtervention. In view of its repeated references to federalism as a bar to injunctive relief against pending state criminal proceedings, even where first amendinent claims are made, ${ }^{170}$ the Supreine Court would likely reject the proposal.

Even if the proposal is not adopted, another principle of exhaustion law assures that the costs of exhaustion will be relatively insignificant in inany speech cases. Sentences for crimes under statutcs that

165. See, e.g., Preiser v. Rodriguez, 411 U.S. 475, 490-92 (1973); Braden v. 30th Judicial Circuit Court, 410 U.S. 484, 490-91 (1973); Picard v. Connor, 404 U.S. 270, 275 (1972); Fay v. Noia, 372 U.S. 391, 419-20 (1963).

166. See Amsterdam 884-86; Developments 1094.

167. See Developments 1097.

168. See Amsterdam 898, 904-06.

169. See Developments 1100-01.

170. E.g., Younger v. Harris, 401 U.S. 37, 44 (1971); Douglas v. City of Jeannette, 319 U.S. 157, 163 (1943); $c f$. Francis v. Henderson, 425 U.S. 536, 551 (1976) (Brennan, J., dissenting) (exhaustion requirement is a more appropriate means of recognizing state interest in controlling its criminal processes than is barring claim because of procedural default). 
raise first amendment problems are typically short. In the absence of a special rule, a short sentence would likely expire before the prisoner had exhausted state remedies. Upon release he would be deprived of an opportunity to present his claims in habeas unless there were sufficient collateral restraints upon him to meet the custody requirement. ${ }^{171}$ In any event, the prisoner would be deprived of much of the benefit of habeas if he were required to serve his jail term before filing his petition. To preserve the habeas remedy where the sentence is short, federal courts have deemed the exhaustion requirement satisfied in such cases unless the state allows post-conviction bail while the prisoner goes forward in the state courts. ${ }^{172}$ This principle is not limited to first amendment claims but may have its most significant impact in sucl cases. Examination of forty-seven first amendment habeas cases reveals that the applicants were often released pending exhaustion of state remedies. ${ }^{173}$ Thus, one effect of the rule on short-sentence exhaustion is to lessen the petitioner's exhaustion costs in first amendinent habeas cases.

5. Procedural Default. Suppose a criminal defendant fails to object before trial, as state law requires, to the racial composition of the grand jury that indicted him, or fails, again in contravention of state law, to make conteinporaneous objection to the admission of a confession at trial, or fails properly to raise some other constitutional claim. Under state law, review of these claims is forever barred by failure to coinply with the procedural rules. So long as the procedural rules are

171. Of course, if the argument prevails that the custody requirement should be satisfied in first amendment habeas corpus claims by a showing of conviction alone, then this consideration standing alone would require no special rule. See text accompanying note 160 supra.

172. See, e.g., In re Shuttlesworth, 369 U.S. 35 (1962); Baldwin v. Lewis, 442 F.2d 29, 33 (7th Cir. 1971); Dawkms v. Crevasse, 391 F.2d 921 (5th Cir. 1968); Greene v. City of Orlando, 313 F. Supp. 583, 584 (M.D. Fla. 1970); Amsterdam 895-96, 898-99; Developments 1100; cf. Hensley v. Municipal Court, 411 U.S. 345, 352 (1973) (dictum) (district court may order prisoner's release pending consideration of his habeas clain).

173. E.g., Smith v. Goguen, 415 U.S. 566, 571 (1974); Hammond v. Adkisson, 536 F.2d 237, 238 (8th Cir. 1976); Thomas v. Crevasse, 415 F.2d 550, 550 n.1 (5th Cir. 1969), cert. denied, 397 U.S. 909 (1970); Glen v. Hongisto, 438 F. Supp. 10, 11-12 (N.D. Cal. 1977); Royal v. Rockingham County Superior Court, 397 F. Supp. 260, 261 (D.N.H. 1975), rev'd on other grounds, 531 F.2d 1084 (1st Cir.), cert. denied, 429 U.S. 867 (1976); Simpson v. Spice, 390 F. Supp. 1271, 1272 (E.D. Wis. 1975); Radich v. Criminal Court, 385 F. Supp. 165, 168 (S.D.N.Y. 1974); Squire v. Pace, 380 F. Supp. 269, 280 (W.D. Va. 1974), aff'd, 516 F.2d 240 (4th Cir.), cert. denied, 423 U.S. 840 (1975); Clime v. Rockingham County Superior Court, 367 F. Supp. 1146, 1147 (D.N.H. 1973), aff'd, 502 F.2d 789 (1st Cir. 1974); Summerlin v. Sheriff, 350 F. Supp. 336, 337 (N.D. Ohio 1972). But see Bloss v. State of Michigan, 421 F.2d 903 (6th Cir. 1970) (district court erred in granting bail pending state court appeal); Simpson v. Spice, 318 F. Supp. 554 (E.D. Wis. 1970) $(\$ 10,000$ bail not excessive in obscenity case); $c$. Goodman v. Kohl, 456 F.2d 863 (2d Cir. 1972) (petitioner must exhaust state court remedies as to bail before pursuing federal habeas for release on bail). 
constitutionally valid, the issues are also barred on direct appeal to the Supreme Court. ${ }^{174}$

Does the petitioner's procedural default bar him from raising the claim im habeas? Because habeas is an entirely separate proceedimg unrelated to the trial im which the default took place, the power of the habeas court to lear such issues is fairly well-settled. ${ }^{175}$ The harder question is whether the power should be exercised. In Fay the prisoner had failed to appeal his state conviction. By the time he filed his habeas petition the deadline for appeal had passed, so his failure to exhaust became a procedural default. ${ }^{176}$ The issue was whether failure to preserve the claim in the state courts would bar collateral review. The Court held that the petition would be barred only if the failure to appeal amounted to a "deliberate by-passing" of state processes. It did not limit the deliberate-bypass standard to failure to appeal but said that all procedural defaults would be tested by that rule. The deliberate-bypass standard required a "considered choice" by the defendant to try to circumvent state adjudication of the claim and was not satisfied where the failure to assert the claim was madvertent. ${ }^{177}$

Thirteen years later, in Francis $v$. Henderson, ${ }^{178}$ the Court ruled that failure to meet the state rule requiring objection before trial to grand jury composition would bar the claim on a habeas corpus petition unless the petitioner could show "cause" for failing to raise the issue and "prejudice" resulting from the alleged constitutional violation. ${ }^{179}$ In Wainwright, the Court held similarly with regard to a contemporaneous objection requirement. In neither of these cases did the Court explaim the content of the "cause" and "prejudice" standard or indicate whether the new rule would be applied to all claims. Instead, it left "open for resolution $\mathrm{m}$ future decisions the precise definition of

174. See, e.g., Henry v. Mississippi, 379 U.S. 443, 446-52 (1965); Fay v. Noia, 372 U.S. 391, 429 (1963); Herb v. Pitcairn, 324 U.S. 117 (1945).

175. See Wainwright v. Sykes, 433 U.S. 72 (1977); Francis v. Henderson, 425 U.S. 536, 538 (1976); Fay v. Noia, 372 U.S. 391, 425 (1963). But see id. at 448 (Harlan, J., dissenting) ("federal courts have no power, statutory or constitutional, to release the respondent . . . because his custody . . . does not violate any federal rights, since it is pursuant to a convietion whose validity rests upon an adequate and independent state ground which the federal courts are required to respect") (einphasis in original).

176. See 372 U.S. at 394. See also Smith v. Sheeter, 402 F. Supp. 624, 626 (S.D. Ohio 1975) (describing how failure to exhaust state remedies can become procedural default).

177. See 372 U.S. at 439.

178. 425 U.S. 536 (1976).

179. Id. $c f$. Estelle v. Williams, 425 U.S. 501 (1976) (holding that a petitioner who had been tried in prison clothes was not denied his right to be tried in civilian clothes when his lawyer failed to object at trial); Davis v. Umited States, 411 U.S. 233 (1973) (federal habeas); see also HART \& WECHSLER 256-58 (Supp. 1977). 
the 'cause' and 'prejudice' standard." 180 The Wainwright Court did acknowledge that the new rule "limited" Fay, ${ }^{181}$ presumably to cases involving a failure to appeal subsequent to trial. ${ }^{182}$ Like the exhaustion requirement, the standards of procedural default announced in Francis and Wainwright are a means of respecting the federalist interest in the integrity and effectiveness of state procedural rules. ${ }^{183}$ Unlike the exhaustion requirement, they do not merely affect the timing of federal habeas; they bar it altogether. ${ }^{184}$

The impact of Francis and Wainwright upon first amendment habeas will remaim uncertain until the Court provides a more "precise definition" of its cause and prejudice standard. There is reason to believe, however, that its impact will be minimal. Of the forty-seven cases that could be found presenting federal habeas corpus petitions based on first amendment claims, the procedural default issue was raised in only three. In no case was procedural default a bar to the habeas proceeding. In two cases, the asserted default was failure to raise a first amendinent argument on appeal. ${ }^{185}$ At least so long as Fay remains the law on that point, procedural default will have little impact in the first amendment context. ${ }^{186}$

The opinions in Francis and Wainwright suggest that Fay may well survive on the issue of failure to appeal, at least where a substantive rather than a procedural ground is advanced in habeas. Those two decisions were motivated by concern for strong state imterests in the effectiveness and integrity of the procedural rules at issue. The Court im Francis stressed the importance of the state rule regarding grand jury objections in accommodating the defendant's right to a properly constituted grand jury and the state's interest $\mathrm{m}$ trying him for the crime as soon as possible. Determming the inerits of the grand jury claim could prove difficult long after the events, as could retrial many years after the crime. Prompt assertion of the grand jury claim would avoid all these problems. ${ }^{187}$ In Wainwright the Court emphasized the importance of the contemporaneous objection rule to the effective and efficient administration of the criminal justice system. The rule helps

180. 433 U.S. at 87.

181. Id. at 85 .

182. See id. at 88 n. 12 .

183. See id. at 88-90; Francis, 425 U.S. at 539-42.

184. See Francis, 425 U.S. at 551 (1976) (Brennan, J., dissenting).

185. Smith v. Sheeter, 402 F. Supp. 624, 626 (S.D. Ohio 1975); Severson v. Duff, 318 F. Supp. 17,19 , opinion on the merits, 322 F. Supp. 4 (M.D. Fla. 1970). The other procedural default case is Epton v. Nenna, 446 F.2d 363, 366-67 (2d Cir.), cert. denied, 404 U.S. 948 (1971) (failure to request jury instruction on proper standard for first amendment privilege).

186. The impact of procedural default in general nay be insignificant. See Shapiro 346-48.

187. 425 U.S. at $540-41$. 
correct errors at an early stage, avoids retrial and assures the perception of a trial "as a decisive and portentous event." 188

Where the procedural default is failure to raise an issue on appeal, the state courts are deprived of an opportunity to decide the claim, but the kind of strong federalist interest in a procedural rule that impressed the Court in Francis and Wainwright is absent. If the issue is one of substantive law, first amendment or otherwise, there will probably be no retrial, so the finality costs of allowing the claim will be less than in the case of a procedural challenge. Moreover, there will be no incentive for a defense attorney to withhold a claim in the state court in the hope of getting a inore favorable forum in federal court, a concern mentioned by the Court in Wainwright in support of its cause and prejudice rnle. ${ }^{189}$ Such an incentive could only be present when a determination of fact is necessary to adjudication of the claim and the lawyer wishes to assure that the federal court will not defer to the state court determination. On issues of substantive law or of the application of law to fact, federal courts do not defer to state court determinations in any event, so there is no incentive not to raise such issues in state courts. Thus, procedural defaults respecting legal issues nearly always will be inadvertent. As noted earlier, first amendment cases generally present either issues of law or of the application of law to fact; the facts are rarely disputed. ${ }^{190}$

In terms of the criteria developed in Part II, then, the interests of federalism and finality in a strict procedural default rule are weaker for substantive claims that liave not been raised on appeal than for the types of procedural default addressed in Wainwright and Francis. Accordingly, a more relaxed rule can be justified. This rationale for preserving Fay for failure to raise substantive claims on appeal is not limited to the first amendment context. Nor would such an approacli guarantee that procedural default would never bar a first amendment claim. ${ }^{191}$ A broader exception for first amendment cases would have to

188. 433 U.S. at 90.

189. See id. at $89-90$.

190. See text accompanying notes 90-94 supra.

191. An example is Epton v. Nenna, 446 F.2d 363, 366-67 (2d Cir.), cert. denied, 404 U.S. 948 (1971), where th = asserted default, not addressed by the court of appeals, was failure to request a jury instruction on the proper test for first amendment privilege. There is, however, at least one other type of procedural default on substantive issues that might fit within the rationale developed in the text for mamtaining Fay for failures to appeal. That situation is where a particular first amendment defense is not raised at all in the state courts. Cf. Smith v. Goguen, 415 U.S. 566, 57677 (1974) (dictum rejecting the state's claim that the petitioner had failed to present to the state courts his argument that the statute was facially vague); Gooding v. Wilson, 405 U.S. 518,519 n.1 (1972) (petitioner had failed to present to state courts his claim that the statute was unconstitutional as apphed). The considerations favoring a relaxed procedural default rule in the appeal 
be based on a judgment that the fragility of first amendment rights and the close connection of free specch claims to the basic justice of the incarceration justify a general deviation from strict procedural default rules in spite of the competing interests in finahty and federahsm. ${ }^{192}$

\section{Overbreadth Review.}

Perhaps the most vexing question in first amendment habeas is whether overbreadth attacks should be permitted. The overbreadth doctrine has already been briefly discussed im connection with the fragility of first amendment rights. ${ }^{193}$ It is a departure from the rule that a litigant may attack the constitutionality of a statute only as it applies to him and not on the basis of hypothetical unconstitutional applications to others. The Supreme Court has permitted such challenges in first amendment cases because the exercise of first amendment rights could be chilled by the existence of the statute. For that reason it is deemed essential to strike down the law in the flrst available case, even if the particular hitigant's actions could properly be reached. Overbreadth analysis is not applied in every case, but only where the law is capable of a substantial number of imperunissible apphications, substantially involves first amendment interests and there is no adequate judicial technique for drawing lines betwcen the vahd and the invahid apphications of the law. ${ }^{194}$

1. The Theoretical Problem. In habeas corpus hitigation the focus of attention is supposed to be the prisoner and the "basic justice" of his incarceration. Overbreadth analysis makes the prisoner and his actions virtually irrelevant. ${ }^{195}$ Yet the Supreme Court and soine lower courts have heard overbreadth attacks on habeas without recognizing

context are also applicable here. There is no incentive for withholding the claim from the state courts; there will be no retrial; and there is no threat posed to state procedural rules. The chief difference between this situation and the failure to raise a point on appeal is that the state may have a stronger interest in having one of its courts examine the constitutional question than in having two of thein do so. It should be kept in mind, however, that the one court would be a trial court, whose basic function is to adjudicate facts and apply law to fact and not to make authoritative pronouncements on constitutional issues.

192. Cf. White, Federal Habeas Corpus: The Impact of the Failure to Assert a Constitutional Claim at Trial, 58 VA. L. REv. 67, 85 (1972) (arguing that "[t]he social importance of vindicating a constitutional claim is one factor a court should consider in determining whether a waiver of the claim by the defendant's attorney will bind the defendant in subsequent proceedings").

193. See text accoinpanying notes 60-63 supra.

194. First Amendment-Overbreadth 858-63; see Erznoznik v. City of Jacksonville, 422 U.S. 205, 216 (1975).

195. In many overbreadth opinions the court does not even discuss the individual's conduct. E.g., Walker v. Dillard, 523 F.2d 3 (4th Cir.), cert. denied, 423 U.S. 906 (1975); Radford v. Webb, 446 F. Supp. 608 (W.D.N.C. 1978); Severson v. Duff, 322 F. Supp. 4 (M.D. Fla. I971). 
any incongruity. ${ }^{196}$ Other courts have held such challengcs to be inappropriate in a habeas proceeding. ${ }^{197}$ None of the opinions suggests that the courts have given much thought to the problem.

This issue deserves greater attention than it has received, especially in view of Stone. ${ }^{198}$ If Stone is the harbinger of a general "innocence" test for determining which issues may be raised on habeas, then collateral review of overbreadth claims is probably doomed. ${ }^{199}$ Only by stretching the concept of innocence out of shape could the Court say that a defendant is innocent in a first amendment case because the statute improperly applies to the hypothetical acts of someone else. ${ }^{200}$

Quite apart from the specific holding in Stone, the personal nature of the writ and its historical function as a remedy for "affronts to the conscience of a civilized society" and those restraints that society finds "intolerable," witl the ultimate object being "basic justice" to the prisoner, ${ }^{201}$ seem inconsistent with overbreadth review. Consider, for example, the contrast between overbreadtl and double jeopardy. A double jeopardy petition may not claim innocence, but at least it asserts the right of the prisoner himself not to be put in jeopardy twice for the same offense, and the focus of attention is on the justice of the prisoner's confineinent. Overbreadtli is not a means of doing justice in the applicant's case, or even a means of protecting his constitutional rights, but rather is aimed at defending the rights of others.

2. The Calculus of Interests. It would, however, be short-sighted to dismiss overbreadtli claims just because they do not fit comfortably within the theory underlying the availability of habeas corpus. Apart

196. E.g., Gooding v. Wilson, 405 U.S. 518 (1972); Walker v. Dillard, 523 F.2d 3 (4th Cir.), cert. denied, 423 U.S. 906 (1975); Squire v. Pace, 516 F.2d 240 (4th Cir.), cert. denied, 423 U.S. 840 (1975); Wiegand v. Seaver, 504 F.2d 303 (5th Cir. 1974), cert denied, 421 U.S. 924 (1975); Radford v. Webb, 446 F. Supp. 608 (W.D.N.C. 1978); Sinith v. Sheeter, 402 F. Supp. 624 (S.D. Ohio 1975); Severson v. Duff, 322 F. Supp. 4 (M.D. Fla. 1971).

197. E.g., Walters v. Clement, 544 F.2d 1340 (5th Cir. 1977); Gagnon v. Cupp, 454 F.2d 287 (9th Cir. 1972); Wenzler v. Pitchess, 359 F.2d 402 (9th Cir. 1966), cert. denied, 388 U.S. 912 (1967); cf. Royal v. Rockingham County Superior Courh, 397 F. Supp. 260, 264 (D.N.H. 1975), rev'd on other grounds, 531 F.2d 1084 (1st Cir.), cert. denied, 429 U.S. 867 (1976) (overbreadth review not appropriate on habeas where statute has been repealed); Radich v. Criminal Court, 385 F. Supp. 165, 170 n.21 (S.D.N.Y. 1974) (because the writ protects personal rights, the court will not use overbreadth analysis when as-apphed review is sufficient to do justice in the case at hand). As to the personal nature of the writ, see the authorities cited at note 29 supra.

198. The question is raised but not discussed in HART \& WeChSLER $210 \mathrm{n} .2$.

199. See Stone v. Powell, 428 U.S. 465,518 n.13 (1976) (Brennan, J., dissenting).

200. But cf. First Amendment-Overbreadth 848 ("As a theoretical matter the claimant is asserting his own right not to be burdened by an unconstitutional rule of law, though naturally the claim is not one which depends on the privileged character of his own conduct") (footnote omitted).

201. See text accompanying notes 19-24 supra. 
from habeas, the only manner in which state statutes may be tested in federal court is by appeal of a conviction to the Supreme Court, ${ }^{202}$ removal of the proceedings to a federal court, ${ }^{203}$ a suit for a declaratory judgment ${ }^{204}$ or a suit for injunctive relief. ${ }^{205}$ Appeal is an unsatisfactory alternative because the Court may, for reasons of its own, decline to examine the merits fully. ${ }^{206}$ Removal is generally unavailable in free speech cases. ${ }^{207}$ Declaratory actions are often barred by lack of a concrete controversy. ${ }^{208}$ When there is a controversy in the form of pending state proceedings, the Supreme Court has limited declaratory and mjunctive relief on the ground that federal imterference with pending state proceedings is inimical to "Our Federalism" unless the state proceedimgs are imstituted or conducted im bad faith. ${ }^{209}$ Thus, habeas corpus might be the only viable federal forum for the assertion of overbreadth claims.

An evaluation of overbreadth review in terms of its impact on federalism and finality is more problematic. In terms of federahism, overbreadth review is inherently nore intrusive than a review limited to a consideration of the validity of a law as applied to the particular facts of the case. But the Supreme Court has determined that the advantages in protecting free speech outweigh this disadvantage. That a case arises on habeas is no reason to count this characteristic intrusiveness agamst it a second tinne. In fact, smce habeas review takes place only after state proceedings have run their course, habeas is a less intrusive way of asserting overbreadth clanns than is removal or a suit for injunctive relief. Furthermore, overbreadth claims are less intrusive than many other kinds of claims on habeas because they do not ever require the relitigation of facts.

The absence of any need to relitigate facts also lowers the finality costs of overbreadth habeas, as does the impossibility of retrial following a successful overbreadth attack. In addition, a relatively high pro-

202. There is a right of appeal to the Supreme Court where a state statute is upheld on its face, as would be the case in an unsuccessful overbreadth attack. 28 U.S.C. § 1257(2) (1976).

203. Id. § 1443(1) (1976).

204. Id. \& 2201 (1976).

205. E.g., 42 U.S.C. $\$ 1983$ (1976).

206. See Stone, 428 U.S. at 526 (Brennan, J., dissenting); England v. Louisiana State Bd. of Medical Examiners, 375 U.S. 411, 416 (1964); A. BrCKer, The Least DaNgerous Branch 126 (1962); HART \& WECHSLER 660-62; Note, The Precedential Effect of Summary Affirmances and Dismissals for Want of a Substantial Federal Question by the Supreme Court After Hicks v. Miranda and Mandel v. Bradley, 64 VA. L. Rev. 117, 125-30 (1978).

207. See Georgia v. Rachel, 384 U.S. 780, 792 (1966).

208. See, e.g., Boyle v. Landry, 401 U.S. 77 (1971).

209. E.g., Samuels v. Mackell, 401 U.S. 66 (1971); Younger v. Harris, 401 U.S. 37 (1971); see Fiss, Dombrowski, 86 Yale L.J. 1103, 1132-33 (1977). 
portion of overbreadth challenges are successful. ${ }^{210}$ The significance of this last point, however, is open to question. These challenges are successful because the statute is too broad, not because the prisoner is necessarily innocent of acts that the state may properly punish. Effective enforcement of the criminal law is surely obstructed when prisoners must be released even though they could properly be punished-all in the interests of protectimg someone else's rights.

3. Compromises. Should overbreadth review be allowed in view of these considerations? Perhaps not, if the integrity of habeas were jeopardized by such an exception to the customary functions of habeas or if the state's finality interest in effective punishment of offenders were valued highly enough. These objections to overbreadth review on habeas might be satisfactorily met only by barring such claims altogether. For example, the obvious suggestion for overcoming the finality objection is to allow only hitigants whose conduct is constitutionally protected to assert overbreadth claims on habeas. A major justification for overbreadth review, however, is that these individuals might be inhibited from exercising their rights in the first place. ${ }^{211}$ Accordingly, such a rule would largely emasculate the overbreadth doctrine as a ineans for dealing effectively with the chilling effect of sweeping laws. In addition, a proper overbreadth case, by definition, involves a statute that the courts caimot rehabilitate by drawing lines to separate protected from unprotected conduct. ${ }^{212}$ Finally, such a rule could make the liberty of an unprotected violator turn on the fortuity of whether his case arises before or after the case of a person whose conduct is protected.

If the finahity interests threatened by the overbreadth doctrine are thought too strong to ignore, a better approach might be to allow overbreadth claims on habeas where the petitioner's conduct is "arguably

210. Among the forty-seven federal first amendment habeas corpus cases listed in the Appendix infra, the court reached the merits of an overbreadth claim in thirteen cases; seven were successful challenges, see cases cited at note 196 supra, and six were unsuccessful, Moore v. Newell, 548 F.2d 671 (6th Cir.), cert. denied, 431 U.S. 971 (1977); Thompson v. Gafiney, 540 F.2d 251 (6th Cir. 1976), cert. denied, 429 U.S. 1078 (1977); Arbeitman v. District Court, 522 F.2d 1031 (2d Cir. 1975); Means v. Solem, 457 F. Supp. 1256 (D.S.D. 1978); Deeds v. Beto, 353 F. Supp. 840 (N.D. Tex. 1973); McLaurin v. Burnley, 279 F. Supp. 220 (N.D. Miss. 1967), aff'd, 401 F.2d 773 (5th Cir. 1968), cert. denied, 399 U.S. 928 (1970).

211. See Erznoznik v. City of Jacksonville, 422 U.S. 205, 216 (1975); Broadrick v. Oklahoma, 413 U.S. 601, 612 (1973); cf. Bates v. State Bar of Ariz., 433 U.S. 350, 380-81 (1977) (overbreadth doctrine "applies weakly, if at all, in the ordinary commercial context," partly because commercial speech is less likely to be inhibited by overbroad laws than is noncommercial speech).

212. See, e.g., Erznoznik v. City of Jacksonville, 422 U.S. 205, 216-17 (1975); Gooding v. Wilson, 405 U.S. 518, 520-21 (1972); Dombrowski v. Pfister, 380 U.S. 479, 497 (1965). 
protected."213 This rule would obviate the need to draw lines between protected and unprotected conduct, ${ }^{214}$ and fortuities could be somewhat mitigated by the retroactive application of decisions striking down statutes on habeas. Moreover, the "arguably protected" standard balances the finality interest with the protective interest embodied in the overbreadth doctrine, thereby saving the fragile first amendment rights from complete subordination to the state's interest in finality. However, the proposed standard seemingly fails to reconcile the theoretical inconsistency between overbreadth review and habeas corpus. ${ }^{215}$ Another coinpromise might be simply to require greater overbreadth in habeas than otherwise. ${ }^{216}$ However, "substantial" overbreadth is already a requisite of overbreadth review. ${ }^{217}$ An additional substantiality requirement is likely to be imprecise and subject to inconsistent application. More importantly, it would impair the effectiveness of the overbreadth doetrine without directly attacking eitler of the perceived ills. Overbreadtl habeas would remain inconsistent with the theory of habeas, and guilty petitioners would still be freed in contravention of the state's finality interest.

Before abandoning overbreadth habeas as inconsistent with the theory and history of the writ, however, certain other aspects of the writ's history should be taken into account. Habeas has survived many changes since the thirteenth century when it was "used for the purpose of getting a party before the court so that a case in which he was in-

213. Under this test the court would not determine whether the petitioner's activity is protected by the first amendinent, but would examine the statute for facial invalidity if the petitioner could make a colorable first amendment argument. For example, overbreadth review would be denied if the petitioner had engaged in bookmaking activities, which clearly are not protected. See Rossitto v. Anderson, 354 F. Supp. 1127 (D. Del. 1973). The impingement upon the state's finality interest is less than it would be under a traditional overbreadth examination, since the "arguably protected" standard would be unavailable to those whose conduct is clearly unprotected. Yet, by according an examination of the facial invalidity of a statute to one whose conduct is arguably-but not necessarily-protected, the proposed standard preserves much of the protection against chill of first amendment rights that the overbreadth doctrine is designed to provide.

This standard is somewhat analogous to the test developed by the Supreine Court in the area of preemption of state law by the federal labor laws, where courts must determine whether the conduct subject to state law is arguably protected or arguably prohibited by federal labor law. San Diego Bldg. Trades Council v. Garmon, 359 U.S. 236 (1959); see Sears, Roebuck \& Co. v. San Diego County Dist. Council of Carpenters, 436 U.S. 180 (1978).

214. See First Amendment-Overbreadth 910 n.262.

215. See text accompanying notes $195-201$ supra.

216. Cf. Broadrick v. Oklahoma, 413 U.S. 601, 615-16 (1973) (suggesting that more overbreadth is required when "conduct and not merely speech is involved"). See generally Note, Overbreadth Review and the Burger Court, 49 N.Y.U.L.REv. 532, 538-43 (1974) (discussing Broadrick).

217. See, e.g., Broadrick v. Oklahoma, 413 U.S. 601, 630-31 (1973) (Brennan, J., dissenting). 
volved could be adjudicated."218 The steady expansion of cognizable issues on a petition is one of these changes. Another is the attenuation of the concept of custody, which also reflects a greater contemporary sensitivity to claims for protection of constitutional rights. Yet in abandoning the physical-restraint requirement, the Supreme Court has abandoned the very foundation underlymg the development of the writ. No more severe break with theory and history could be imagined. Similarly, the exhaustion requirement is foreign to the nature and purpose of the writ, but was engrafted onto it by the Supreme Court as a way of preserving the values of federalism. In deciding whether the advantages of overbreadth review warrant a deviation from the deInands of theory or of the more specific rule of Stone, the Court should keep this historical flexibility in mind. The theoretical integrity of habeas is important, but it has never been sacred. ${ }^{219}$

\section{Conclusion: The Contextual Approach}

A comprehensive account of the contextual approach to habeas requires an analysis of the intrusions on federalism and finality of each kind of habeas claim, a determination of whether there exists a special need for habeas in connection with each particular constitutional right and determinations as to which rights are most closely related to the historical function of habeas-to lift intolerable restraints and to work basic justice. No coinprehensive account is needed, however, in order to conclude that first amendment habeas is distinctive and warrants inore liberal treatment no matter how procedural rights are handled. In addition, some of the principles applicable to first amendment claims can be applied in other contexts. For example, to the extent that special treatment for first amendment habeas petitions rests on the substantive cliaracter of the rights at stake, such as the relationship of free

218. D. MEADOR, supra note 18 , at 8.

219. In connection with overbreadth habeas, the case of Peters v. Kiff, 407 U.S. 493 (1972), is worth noting. In that habeas case, a white man was permitted to challenge his conviction on the basis that the grand and petit jury selection process discriminated agamst blacks. Three members of the Court voted to permit the challenge on the ground that the prisoner's own rights may have been violated, since "the exclusion from jury service of a substantial and identifiable class of citizens has a potential impact that is too subtle and too pervasive to admit of confinement to particular issues or particular cases." Id. at 503. Three members of the Court concurred in the judgment on reasoning analogous to the justification for overbreadth. They pointed out that a federal statute, 18 U.S.C. $\$ 243$ (1976), makes it a crime to discrimmate on the basis of race in selecting jurors and said they "would implement the strong statutory policy of $\$ 243$, which reflects the central concern of the Fourteenth Amendment with racial discrinimation, by permitting petitioner to challenge his conviction on the ground that Negroes were arbitrarily excluded from the grand jury that indicted him." 407 U.S. at 507. They did not address the further question whether such an attack is appropriate on a habeas corpus petition. 
speech rights to the history and theory of habeas ${ }^{220}$ and in connection witl diminished finality costs, ${ }^{221}$ the same justification might be offered for liberal review of other substantive rights claimed on habeas. ${ }^{222}$

There may be other rights that share the fragility of free speech or otherwise deserve special attention. One situation that comes quickly to mind is that of the prisoner condemned to death. Sliould not his petition be exempt from strict procedural default rules and the new limits on cognizability? At the root of habeas is the principle tliat confinement is sufficient reason to override the ordmary rules of res judicata. The prospect of deatl may be deemed good reason to ignore ordinary rules of liabeas practice. ${ }^{223}$

Fragile riglits are also at stake when a prisoner asserts that the riglits of third persons are violated by the application of a law to his conduct. $^{224}$ For example, suppose the state makes it a crime to give away contraceptives to single persons, and a person convicted of the crime asserts on a petition for liabeas corpus that the statute violates not his own riglits but the rights of unmarried persons to receive contraceptives. 225 Standing to assert jus tertii is ordmarily allowed when

220. See text accompanying notes 54-77 supra.

221. See text accompanying notes 90-102 supra.

222. Apart from free speech claims, the substantive issues most often litigated in habeas appear to be those based on vagueness and privacy. E.g., Rose v. Locke, 423 U.S. 48 (1975) (writ denied); Wainwright v. Stone, 414 U.S. 21 (1973) (writ denied); Balthazar v. Superior Court, 573 F.2d 698 (1st Cir. 1978) (writ granted); Gable v. Massey, 566 F.2d 459 (5th Cir.), cert. denied, 435 U.S. 975 (1978) (writ denied); Lovisi v. Slayton, 539 F.2d 349 (4th Cir.), cert. denied, 429 U.S. 977 (1976) (writ denied); Scott v. District Attorney, 309 F. Supp. 833 (E.D. La. 1970), aff'd, 437 F.2d 500 (5th Cir. 1971) (writ granted).

223. For example, in Brown v. Allen, 344 U.S. 443, 482-87 (1953), a capital case, the petitioner had not met a sixty-day deadline for serving the statement of the case on appeal. Although the statement was delivered on the 61st day, Fay had not yet been decided, and this procedural violation was held to bar habeas. Even under a scheme of strict procedural default, this result seems unduly harsh when the prisoner is condemned to death. $\mathcal{C}$. White, supra note 192, at 82-85 (standard for procedural default should depend in part on the social importance of the rights asserted).

224. See generally Note, Standing to Assert Constitutional Jus Tertii, 88 HARv. L. Rev. 423 (1974).

225. These are the basic facts of Eisenstadt v. Baird, 405 U.S. 438 (1972). The Court granted the writ without considering the problems raised by a jus tertii claim in habeas. The issue is raised but not explored in HART \& WeChSLer 187 n.1. See Mucie v. Missouri State Dep't of Corrections, 543 F.2d 633 (8th Cir. 1976) (implicitly perinitting abortionist to raise his patient's right to privacy); Caesar v. Mountanos, 542 F.2d 1064, 1069 (9th Cir. 1976), cert. denied, 430 U.S. 954 (1977) (not permitting psychiatrist to raise his patient's right to privacy); Vuitch v. Hardy, 473 F.2d 1370 (4th Cir.), cert. denied, 414 U.S. 824 (1973) (implicitly perınitting abortionist to raise his patient's right to privacy); United States ex rel. Williams v. Zelker, 445 F.2d 451 (2d Cir. 1971), opinion on the merits sub nom. United States ex rel. Williams v. Preiser, 497 F.2d 337 (2d Cir.), cert. denied, 419 U.S. 1058 (1974) (imphitly permitting abortionist to raise his patient's right to privacy); Ketchum v. Ward, 422 F. Supp. 934 (W.D.N.Y. 1976), aff'd, 556 F.2d 557 (2d Cir. 1977) (implicitly permitting abortionist to raise his patient's right to privacy, but denying the writ on the merits); $c$. Spears v. Circuit Court, 517 F.2d 360 (5th Cir. 1975) (not permitting a nonphysician to challenge an abortion statute on habeas); Harling v. Department of Health and Social Services, 
there is a close relationship between the claimant and the third person, when it is impossible for the third person to assert his rights, and when a refusal to allow assertion of jus tertii would result in a dilution of the third person's rights. ${ }^{226}$

The parallels of jus tertii to overbreadth analysis are readily apparent. But there is also a significant difference. If an overbreadth claim is not permitted, the protected persons will remain able to assert their rights in the event the statute is apphied to thein. If assertions of jus tertii are not allowed, the protected person will be foreclosed because his rights "are at stake in the actual proceeding in which the jus tertii claim is raised."227 Enjoynent of constitutional rights may be chilled in the overbreadth context, but refusal to grant standing to assert jus tertii will forever bar the protected individuals from vindicating their rights. ${ }^{228}$

The contextual approach to the availability of habeas corpus is not without difficulties. To devise a general theory of context, the courts would need to resolve many novel issues concerning the functions and the relative fragility of rights and identify subtle differences in the strength of the interests in finahty and federalism among the various contexts. Coutextual comparisons among procedural rights, most of which serve roughly the same function of guaranteeing fair process and entail roughly similar intrusions upon finality and federalist values, may not result in useful contextual distinctions. The first amendment, however, is one area where reasonably sharp distinctions based on context can be drawn. Some other possibilities have been noted in the preceding paragraphs. And, of course, the suggestions made here are not intended to be exhaustive. Properly einployed, the examination of context can play an important, if limited, role in the debate over the proper scope of habeas corpus. Consideration of context can illuminate the value choices that habeas requires and consequently can facilitate the making of rules that more accurately reflect the shifting strengths of the interests at stake as the discussion moves from one constitutional right to another.

323 F. Supp. 899 (E.D. Wis. 1971) (permitting a nonphysician to challenge an abortion statute on habeas).

226: See Eisenstadt v. Baird, 405 U.S. 438, $443-46$ (1972); Note, supra note 224, at 425.

227. First Amendment-Overbreadth 848 n.18.

228. See Note, supra note 224 , at $435-36,438-40$. 
Appendix-Published Federal First Amendment Habeas Corpus Decisions Arising From State Court Convictions 1963-1978

\author{
United States Supreme Court
}

Smith v. Goguen, 415 U.S. 566 (1974) (flag desecration; writ granted).

Gooding v. Wilson, 405 U.S. 518 (1972) (profane language; writ granted).

\title{
Decisions Within:
}

\section{The First Circuit}

Royal v. Rockingham County Superior Court, 531 F.2d 1084 (Ist Cir.), cert. denied, 429 U.S. 867 (1976) (flag desecration; writ granted).

Cline v. Rockingham County Superior Court, 502 F.2d 789 (1st Cir. 1974) (flag desecration; writ granted).

Hunt v. Keriakos, 428 F.2d 606 (1st Cir.), cert. denied, 400 U.S. 929 (1970) (obscenity; writ granted).

\section{The Second Circuit}

Arbeitman v. District Court, 522 F.2d 1031 (2d Cir. 1975) (obstructing traffic in the course of a demonstration; writ denied).

Epton v. Nenna, 446 F.2d 363 (2d Cir.), cert. denied, 404 U.S. 948 (1971) (conspiracy to riot; writ demed) (procedural default issue-failure to request jury instruction).

Radich v. Criminal Court, 385 F. Supp. 165 (S.D.N.Y. 1974) (casting contempt on the flag; writ granted).

\section{The Third Circuit}

Rossitto v. Anderson, 354 F. Supp. 1127 (D. Del. 1973) (bookınaking; writ denied).

\section{The Fourth Circuit}

Wright v. Bailey, 544 F.2d 737 (4th Cir. 1976), cert. denied, 434 U.S. 825 (1977) (disorderly conduct; writ denied because $\$ 50$ fine was not a sufficient restraint to constitute custody).

Walker v. Dillard, 523 F.2d 3 (4th Cir.), cert. denied, 423 U.S. 906 (1975) (telephone profanity; writ granted).

Squire v. Pace, 516 F.2d 240 (4th Cir.), cert. denied, 423 U.S. 840 (1975) (disorderly conduct; writ granted).

Radford v. Webb, 446 F. Supp. 608 (W.D.N.C. 1978) (profamity over the telephone; writ granted).

\section{The Fifth Circuit}

Walters v. Clement, 544 F.2d 1340 (5th Cir. 1977) (loitering and prowling; statute attacked as overbroad but court said overbreadth not appropriate in habeas; writ denied).

McKinney v. Parsons, 513 F.2d 264 (5th Cir.), cert. denied, 423 U.S. 960 (1975) (obscernty; writ denied).

Wiegand v. Seaver, 504 F.2d 303 (5th Cir. 1974), cert. denied, 421 U.S. 924 (1975) (disorderly conduct; writ granted).

Pickens v. Texas, 497 F.2d 981 (5th Cir.), cert. denied, 419 U.S. 880 (1974) (disorderly conduct; writ demied).

Thomas v. Crevasse, 415 F.2d 550 (5th Cir. 1969), cert. denied, 397 U.S. 909 (1970) (contempt for passing out handbills in front of grand jury room; writ granted).

Hillegas v. Sams, 349 F.2d 859 (5th Cir. 1965), cert. denied, 383 U.S. 928 (1966) (vagrancy; writ deried for failure to exhaust state remedies).

Brown v. Rayfleld, 320 F.2d 96 (5th Cir.), cert. denied, 375 U.S. 902 (1963) (parading without 
a permit; writ denied for failure to exhaust state remedies).

Deeds v. Beto, 353 F. Supp. 840 (N.D. Tex. 1973) (flag desecration; writ denied).

Gornto v. McDougall, 336 F. Supp. 1372 (S.D. Ga. 1972), dismissed as moot, 482 F.2d 361 (5th Cir. 1973) (obscenity; writ denied).

Severson v. Duff, 322 F. Supp. 4 (M.D. Fla. 1970) (disorderly conduct; writ granted) (procedural default issue due to failure to appeal in state court, discussion in an earlier opinion, $318 \mathrm{~F}$. Supp. 17, 19 (M.D. Fla. 1970), held not a deliberate bypass).

McLaurin v. Burnley, 279 F. Supp. 220 (N.D. Miss. 1967), affd, 401 F.2d 773 (5th Cir. 1968), cert. denied, 399 U.S. 928 (1970) (breach of the peace; writ denied).

\section{The Sixth Circuit}

Moore v. Newell, 548 F.2d 671 (6th Cir.), cert. denied, 431 U.S. 971 (1977) (extortion; statute challenged as overbroad; writ denied).

Thompson v. Gaffney, 540 F.2d 251 (6th Cir. 1976), cert. denied, 429 U.S. 1078 (1977) (disorderly conduct; writ denied).

Smith v. Sheeter, 402 F. Supp. 624 (S.D. Ohio 1975) (disruption of college activities; writ granted) (procedural default issue-failure to appeal in state courts held not a deliberate bypass).

Summerlin v. Sheriff, 350 F. Supp. 336 (N.D. Ohio 1972) (obscenity; writ granted).

\section{The Seventh Circuit}

Alnato v. Divine, 558 F.2d 364 (7th Cir. 1977) (obscenity; writ granted).

Orito v. Powers, 479 F.2d 435 (7th Cir. 1973) (obscenity; writ granted).

Raby v. Woods, 440 F.2d 478 (7th Cir. 1971) (blocking traffic in the course of a demonstration; writ denied; evidentiary hearing in the district court).

Heilman v. Wolke, 427 F. Supp. 730 (E.D. Wis. 1977) (contenpt, advertising; writ denied).

Simpson v. Spice, 390 F. Supp. 1271 (E.D. Wis. 1975) (obscenity; writ granted).

Simpson v. Spice, 318 F. Supp. 554 (E.D. Wis. 1970) (obscenity; writ denied for failure to exhaust state remedies).

\section{The Eighth Circuit}

Hammond v. Adkisson, 536 F.2d 237 (8th Cir. 1976) (profane language; writ granted, but the state was pernitted to retry the petitioner under a proper test).

Russell v. City of Pierre, 530 F.2d 791 (8th Cir.), cert. denied, 429 U.S. 855 (1976) (disorderly conduct; writ denied because $\$ 25$ fine was not sufficient restraint to satisfy the custody requirement).

Means v. Solem, 457 F. Supp. 1256 (D.S.D. 1978) (riot statute challenged on overbreadth and other grounds; writ denied).

Means v. Solem, 440 F. Supp. 544 (D.S.D. 1977) (state court revoked bail for exercise of first amendment rights; writ granted).

\section{The Ninth Circuit}

Naylor v. Superior Court, 558 F.2d 1363 (9th Cir. 1977), cert. denied, 435 U.S. 946 (1978) (loitering; writ denied; case was moot since there were no longer any restraimts on petitioner nor any collateral consequences of his conviction).

Wasserman v. Municipal Court, 543 F.2d 723 (9th Cir. 1976) (obscenity; writ denied).

Farr v. Pitchess, 522 F.2d 464 (9th Cir. 1975), cert. denied, 427 U.S. 912 (1976) (newsinan asserting first amendment privilege against disclosing infornation held in contempt; writ denicd).

Gagnon v. Cupp, 454 F.2d 287 (9th Cir. 1972) (soliciting for a prostitute; statute challenged on overbreadth grounds; writ denied).

Pinkus v. Pitchess, 429 F.2d 416 (9th Cir.), aff'd by an equally divided court, 400 U.S. 922 (1970) (obscenity; writ granted).

Wenzler v. Pitcless, 359 F.2d 402 (9th Cir. 1966), cert. denied, 388 U.S. 912 (1967) (obscenity; 
writ denied).

Glen v. Hongisto, 438 F. Supp. 10 (N.D. Cal. 1977) (labor organizer in contenipt; writ granted).

Maita v. Whitmore, 365 F. Supp. 1331 (N.D. Cal. 1973), rev'd on other grounds, 508 F.2d 143 (9th Cir. 1974), cert. denied, 421 U.S. 947 (1975) (contempt, nightclub act; writ denied on the first aniendnient claim).

Hairston v. Pitchess, 323 F. Supp. 784 (C.D. Cal. 1971) (sentence imposed upon conviction for remaining at the scene of a riot challenged as chilling others' first amendment rights; writ denied). 


$$
\text { . }
$$

